Интернет-журнал «Науковедение» ISSN 2223-5167 http://naukovedenie.ru/

Том 7, №1 (2015) http://naukovedenie.ru/index.php?p=vol7-1

URL статьи: http://naukovedenie.ru/PDF/112EVN115.pdf

DOI: 10.15862/112EVN115 (http://dx.doi.org/10.15862/112EVN115)

\title{
УДК 332.146.2
}

\section{Филатов Владимир Владимирович}

ФГБОУ ВО «Московский Государственный Университет технологий и управления им. К.Г. Разумовского (ПКУ)» Россия, Москва ${ }^{1}$

Доцент кафедры «Менеджмента» Кандидат технических наук

E-mail: filatov_vl@mail.ru

\section{Борисова Татьяна Александровна}

ФГБОУ ВО «Московский Государственный Университет технологий и управления им. К.Г. Разумовского (ПКУ)»

Россия, Москва

Доцент кафедры «Экономика и управление на предприятиях малого и среднего бизнеса»

Кандидат экономических наук

E-mail: borgurin@mail.ru

\section{Медведев Владимир Михайлович}

МАИ «Московский авиационный институт (национальный исследовательский университет)»

Россия, Москва

Заведующий кафедрой «314Б» «Управление и информатика в технических системах»

Кандидат технических наук, доцент

E-mail: km@mgutm.ru

\section{Шестов Андрей Владимирович}

ФГБОУ ВО «Московский Государственный Университет технологий и управления им. К.Г. Разумовского (ПКУ)»

Россия, Москва

Доцент кафедры «Менеджмента»

Кандидат экономических наук

E-mail: av2018@mail.ru

${ }^{1} 109004$ Москва, Земляной вал, 73 


\section{Фадеев Александр Сергеевич}

МГТУ «Московский Государственный Технический Университет им. Баумана»

Россия, Москва

Доктор технических наук, профессор

E-mail: km@mgutm.ru

\section{Прогнозы и ключевые тенденции глобального рынка IT}

Аннотация. В данной статье исследованы ключевые тенденции и проведены прогнозы развития глобального рынка IT. Рост уровня зрелости ИТ, стремление сократить издержки и ряд других факторов приводят многие компании к необходимости передать часть инфраструктуры, включающей не только оборудование, но и управление отдельными информационными системами, в дата - центры. В работе проанализированы ключевых тенденций, качественно меняющие развитие рынка телекоммуникационных услуг и технологий, а именно: стандартизация отрасли (требования стандарта TIER); повышение энергоэффективности; растущие объемы трафика и увеличивающаяся необходимость обрабатывать массивы неструктурированных данных; виртуализация; модульность/ мобильность; продуктизация; полная автоматизация. Установлено, что всех участников на российском рынке услуг дата - центров можно условно поделить на четыре группы. Проанализирована текущая емкость российского рынка и рынка г. Москвы, г. СанктПетербурга и Ленинградской области. Составлен рейтинг Топ-10 компаний, размещающих оборудование в дата - центрах Санкт-Петербурга. Составлен рейтинг Топ-7 самых востребованных услуг и их стоимость в Санкт-Петербурге. Установлено, российский рынок отстает в своем развитии от рынков Европы и США примерно на 5 лет. Исследован объем рынка облачных технологий по сегментам в 2013г. Представлен прогноз развития российского телекоммуникационного рынка до 2018г. На основании сделанных прогнозов роста телекоммуникационного рынка емкость рынка этого сегмента в выручке дата - центров к 2020г. может составить 1,7 млрд. руб. Составлен рейтинг сегментов клиентов операторов телекоммуникационного рынка. Проанализирована доля российских компаний использующих инсталляционный платеж в \% от арендной платы. Установлено, что количество дата - центров на рынке будет увеличиваться, причем возможно появление крупных ЦОД. Рынок коммерческих дата - центров развивается, будет увеличиваться набор услуг и повышаться их качество, уменьшаться время реакции на запросы, организацию оригинальных акций для арендаторов. Однако, эта ситуация будет меняться по мере развития рынка, постепенно приближаясь к распределению на уже сформировавшемся рынке США, на котором доля коммерческих операторов составляет всего $37 \%$.

Ключевые слова: информационные технологии (ИТ); центр обработки информации (ЦОД); дата-центры; рынок IT; прогноз; ключевые тенденции.

Ссылка для цитирования этой статьи:

Филатов В.В., Борисова Т.А., Медведев В.М., Шестов А.В., Фадеев А.С. Прогнозы и ключевые тенденции глобального рынка IT // Интернет-журнал «НАУКОВЕДЕНИЕ» Том 7, №1 (2015)

http://naukovedenie.ru/PDF/112EVN115.pdf (доступ свободный). Загл. с экрана. Яз. рус., англ. DOI:

$10.15862 / 112 \mathrm{EVN} 115$ 
Стремление сократить издержки, рост уровня зрелости информационных технологий (ИТ) и ряд других факторов приводят многие компании к необходимости передать часть инфраструктуры, включающей не только оборудование, но и управление отдельными информационными системами, в дата-центры. Рынок центров обработки информации (ЦОД) имеет несколько ключевых тенденций, качественно меняющих его развитие[1-8]:

1. Стандартизация отрасли. Основным сертификатом качества ЦОД в мире является стандарт TIER, выдаваемый компанией The Uptime Institute ${ }^{2}$, открывшей недавно российское подразделение. Сертификат предполагает резервирование в ЦОДе всех инженерных подсистем, а также возможность проведения плановых ремонтных работ и замены оборудования без остановки сервисов и имеет три ступени: Design Documents (сертификация проектной документации), Constructed Facility (сертификация построенного ЦОДа) и Operational Sustainability (операционная устойчивость) ${ }^{3}$, табл.1.

Таблица 1.

Tребования стандарта TIER

\begin{tabular}{|c|c|c|c|c|}
\hline Характеристики ЦОД & Tier 1 & Tier 2 & Tier 3 & Tier 4 \\
\hline $\begin{array}{l}\text { Пути охлаждения и } \\
\text { электричества }\end{array}$ & Один & Один & $\begin{array}{c}\text { Один актив- } \\
\text { ный и один } \\
\text { резервный }\end{array}$ & Два активных \\
\hline $\begin{array}{l}\text { Резервирование } \\
\text { компонентов }\end{array}$ & $\mathrm{N}$ & $\mathrm{N}+1$ & $\mathrm{~N}+1$ & $2 *(\mathrm{~N}+1)$ \\
\hline $\begin{array}{l}\text { Деление на несколько } \\
\text { автономных блоков }\end{array}$ & Нет & Нет & Нет & Да \\
\hline $\begin{array}{l}\text { Возможность горячей } \\
\text { замены }\end{array}$ & Нет & Нет & Да & Да \\
\hline Здание & $\begin{array}{l}\text { Часть или } \\
\text { этаж }\end{array}$ & $\begin{array}{l}\text { Часть или } \\
\text { этаж }\end{array}$ & $\begin{array}{l}\text { Отдельно } \\
\text { стоящее }\end{array}$ & $\begin{array}{l}\text { Отдельно } \\
\text { стоящее }\end{array}$ \\
\hline Персонал & Нет & $\begin{array}{c}\text { Не менее од- } \\
\text { ного инжене- } \\
\text { ра в смене }\end{array}$ & $\begin{array}{c}\text { Не менее } \\
\text { двух инжене- } \\
\text { ров в смене }\end{array}$ & $\begin{array}{c}\text { Более двух } \\
\text { инженеров, } \\
\text { 24-часовое } \\
\text { дежурство }\end{array}$ \\
\hline Загрузка мощностей, \% & 100 & 100 & 90 & 90 \\
\hline $\begin{array}{l}\text { Вспомогательные } \\
\text { площади, \% }\end{array}$ & 20 & 30 & $80-90$ & $100+$ \\
\hline Высота фальш-пола, см & 40 & 60 & $100-120$ & $100-120$ \\
\hline Нагрузка на пол, кг/м2 & 600 & 800 & 1200 & 1200 \\
\hline Электричество & $208-480 \mathrm{~B}$ & $208-480 \mathrm{~B}$ & $12-15$ кВ & $12-15 \kappa B$ \\
\hline Число точек отказа & $\begin{array}{c}\text { Много + } \\
\text { ошибки опе- } \\
\text { ратора }\end{array}$ & $\begin{array}{c}\text { Много + } \\
\text { ошибки опе- } \\
\text { ратора }\end{array}$ & $\begin{array}{c}\text { Мало + } \\
\text { ошибки опе- } \\
\text { ратора }\end{array}$ & $\begin{array}{l}\text { Нет + ошиб- } \\
\text { ки оператора }\end{array}$ \\
\hline
\end{tabular}

2 THE UPTIME INSTITUTЕ ПРИСВОИЛ DАТАSPACЕ СЕРТИФИКАТ НАДЁЖНОСТИ - TIER III FACILITY, ПЕРВЫЙ В ВОСТОЧНОЙ ЕВРОПЕ httр://www.dataspace.ru/news/detail/news/dataspace-awarded-tier-iii-by-uptimeinstitite-first-in-eastern-europe/

${ }^{3}$ Operational Sustainability: как это делается http://iksmedia.ru/articles/5116532-Operational-Sustainability-kaketo.html 


\begin{tabular}{|l|c|c|c|c|}
\hline \multicolumn{1}{|c|}{ Характеристики ЦОД } & Тier 1 & Tier 2 & Tier 3 & Tier 4 \\
\hline $\begin{array}{l}\text { Допустимое время простоя в } \\
\text { Од, ч }\end{array}$ & 28,8 & 22 & 1,6 & 0,4 \\
\hline $\begin{array}{l}\text { Время на создание инфра- } \\
\text { структуры, мес. }\end{array}$ & 3 & $3-6$ & $15-20$ & $15-20$ \\
\hline $\begin{array}{l}\text { Год создания первого ЦОД } \\
\text { подобного класса }\end{array}$ & 1965 & 1975 & 1980 & 1995 \\
\hline
\end{tabular}

(Составлено авторами)

В США и Европе существует свои стандарты, регламентирующие постройку ЦОД. Например, американский стандарт TIA-942 ${ }^{4}$ и его европейский аналог -EN 50173-55. Помимо документа, подтверждающего уровень надежности, существуют и сертификаты, свидетельствующие о безопасности предоставляемых КЦОД услуг (ISO/IEC 27001 и Payment Card Industry Data Security Standard (PCI DSS) ${ }^{6}$ и энергоэффективности объекта (Certified Energy Efficiency Data Center Award (CEEDA) ${ }^{7}$.На сегодня лишь несколько крупных российских дата-центров сертифицированы на выполнение требований Tier III (например, DataSpace1, Сбербанк, МегаФон, КРОК $)^{8}$. Однако, многие дата-центры, позиционирующие себя как ЦОДы уровня Tier III и выше, на деле таковыми не являются. К сожалению, формирование предложения услуг с учетом подобных «условно Tier III-IV» объектов искажает реальную картину рынка и дает разницу в оценках отраслевых аналитиков[9].

2. Повышение энергоэффективности. Затраты на электричество являются основными регулярными платежами крупного ЦОД, к тому же возможности по присоединению зачастую ограничены. Например, в г. Алтуна (шт. Айова, США) Facebook готовит передовой ЦОД Catapult с ветрогенераторами и охлаждением от собираемых атмосферных осадков, который по предварительным оценкам обойдется ей в $\$ 1,5$ млрд. Предполагается, что за счет этих решений энергоэффективность ЦОДа будет на $70 \%$ выше, чем у традиционных.

3. BIG DATA. Растущие объемы трафика и увеличивающаяся необходимость обрабатывать массивы неструктурированных данных.

4. Виртуализация. По мнению аналитиков J'son \& Partners Consulting 9 и основных игроков рынка, одна из ключевых тенденций сегодняшнего рынка ЦОДов - рост заинтересованности в более сложных, комплексных услугах. Зарубежный рынок показывает, что большинство крупных компаний предпочитает набирающую обороты облачную модель

\footnotetext{
${ }^{4}$ Tia 942 http://hl.mailru.su/mcached?q=\%D0\%B0\%D0\%BC\%D0\%B5\%D1\%80\%D0\%B8\%D0\%BA\%D0\%B0\% D0\%BD\%D1\%81\%D0\%BA\%D0\%B8\%D0\%B9\%20\%D1\%81\%D1\%82\%D0\%B0\%D0\%BD\%D0\%B4\%D0\%B0\%D1\% $80 \% \mathrm{D} 1 \% 82 \% 20 \mathrm{TIA}-942 \& \mathrm{c}=14-1 \% 3 \mathrm{~A} 232-$

$1 \& \mathrm{r}=11779886 \& \mathrm{rch}=1 \& q u r l=h t t p \% 3 \mathrm{~A} / /$ lindex.ru/upload/iblock/84a/84a93ec731db55271699fd715fec3a5e.pdf \&fr=webh sm

${ }^{5}$ Проектирование ЦОД http://rvip.ru/1065/document1078.shtml

${ }^{6}$ PCI DSS (Payment Card Industry Data Security Standard) http://www.itgovernance.co.uk/ pci_dss.aspx\#.VN_NkeYcSh0

${ }^{7}$ Savvis Earns Silver CEEDA Honor for Data Center Energy Efficiency http://www.turtleconsulting.com/blog/savvisearns-silver-ceeda-honor-data-center-energy-efficiency/

${ }^{8}$ От зрелости технологий - к зрелости бизнеса и сервисов http://www.iksmedia.ru/articles/4430605-Ot-zrelostitexnologij-k-zrelosti.html

${ }^{9}$ Аналитические отчеты J'son \& Partners Consulting

http://web.json.ru/markets_research/analytical_reports/detail/?report_id=3849
} 
$\mathrm{IaaS}^{10}$. Основная причина этому - экономическая нестабильность[17-18]. Иные причины перечислены ниже, по результатам анкетирования лиц, принимающих решения в крупных компаниях США, проведенного исследовательской компанией Brocade в 2012г., рис.1.

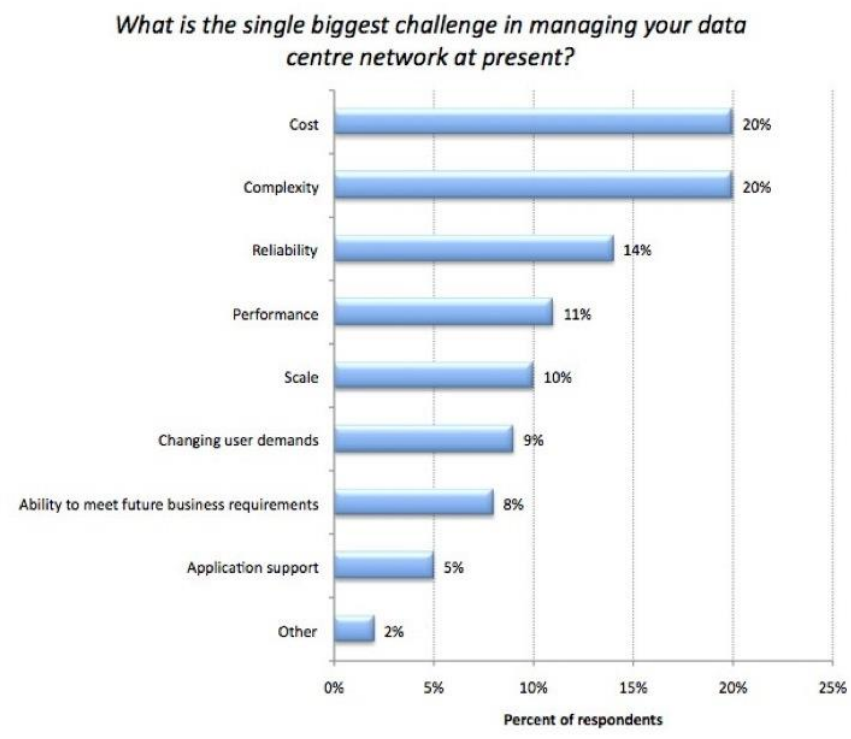

Рисунок 1. Результаты анкетирования лии, принимающих решения в крупных компаниях США, проведенного исследовательской компанией Brocade в 20122. ${ }^{11}$

К облачной модели предоставления услуг дата-центра большинство из них (69\%) отнеслись положительно, а 13\% сказали, что уже используют виртуальный ЦОД, рис.2.

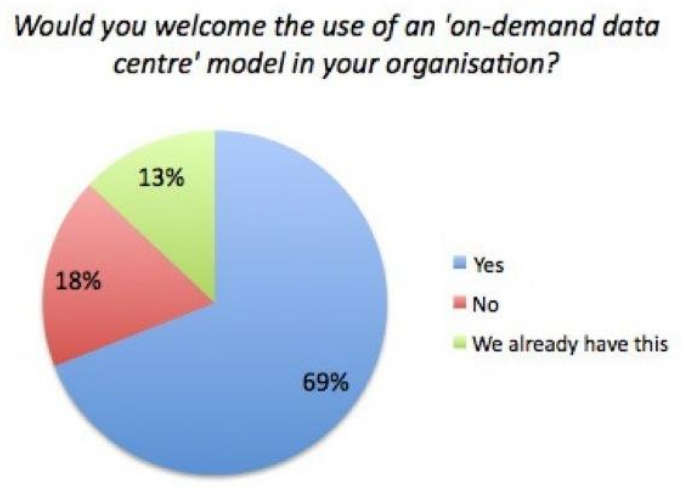

Рисунок 2. Результаты анкетирования лии, принимающих решения в крупных компаниях США, проведенного исследовательской компанией Brocade в 20122. ${ }^{12}$

5. Модульность/Мобильность. Мобильные ЦОД. Это дата-центры, которые, как правило, размещаются в стандартных грузовых $20-40$-футовых контейнерах, оборудованных всей необходимой инженерией. Именно низкая стоимость и скорость развёртывания оказались для НР ключевыми факторами перехода на модульное строительство. «Большинство людей считают, что модульный дизайн - это не вполне надёжное решение для быстрого масштабирования, но это не так» прокомментировал ИТ-

\footnotetext{
${ }^{10}$ Какая облачная модель перспективнее — IaaS или PaaS? http://www.pcweek.ru/its/article/detail.php?ID=158029

${ }^{11} \mathrm{http}: / / \mathrm{www} \cdot$ brocade.com/index.page

12 http://www.brocade.com/index.page
} 
стратег HР Дейв Розеро (Dave Rotheroe) ${ }^{13}$. По словам ИТ-стратега НР Дейва Розеро (Dave Rotheroe), строительство модульного ЦОДа обошлось компании на 20\% дешевле, чем развёртывание обычного дата-центра.

6. Продуктизация. По мнению Крис Кросби из Compass Datacenters ${ }^{14}$ мировой рынок центров обработки данных сейчас находится примерно в середине пятилетнего периода созревания. И этот период характеризуется трендом под названием «продуктизация», который возник из процесса стандартизации отрасли[14-15]. Этот тренд характеризует переход от корпоративных к коммерческим ЦОДам, когда каждая услуга или решение оформлена маркетируется отдельно, позволяя клиентам легче сравнивать предложения от разных компаний.

7. Полная автоматизация. К концу 2015 году совершенно точно появятся датацентры, где людей не будет вовсе. Компания FANUC уже разрабатывает специальных роботов для ЦОДов. IBM, Fidelity Investments и Telefonica активно внедряют роботизированные системы управления дата-центром. Blue Prism создаёт софтверные системы автоматизации[10]. Далее, проведем описание основных сегментов рынка по видам услуг и его участников. В настоящий момент основными услугами, предоставленными на рынке, являются услуги по аренде оборудования (Colocation) и серверов (Dedicated) - в сумме порядка $60 \%$ по выручке, рис.3.

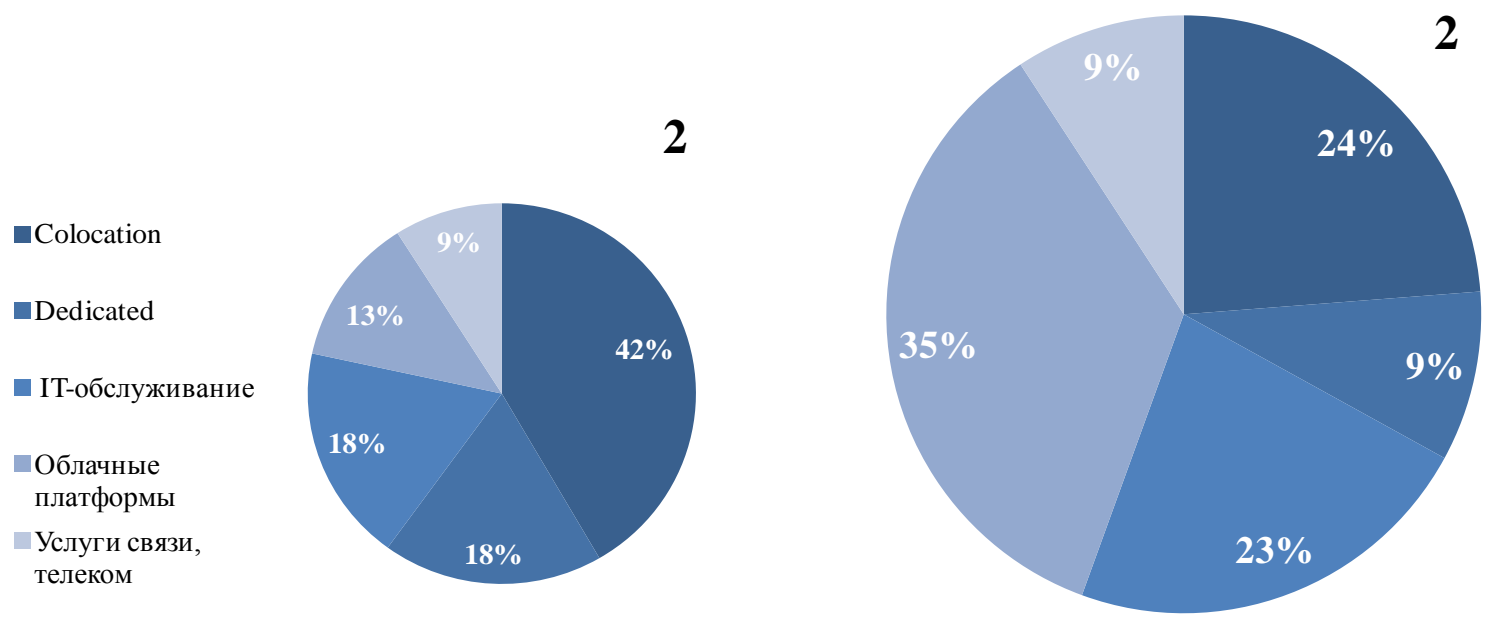

Рисунок 3. Структура выручки по видам услуг. (Составлено авторами)

Далее, рассмотрим сегменты рынка по регионам. В настоящий момент Москва и Московская область являются лидером по размещению дата-центров сосредоточено 77\% доходов российского рынка коммерческих дата-центров и $67 \%$ коммерческих площадей, рис. 4 .

${ }^{13}$ ЦОД-конструктор: почему модульные дата-центры вскоре захватят рынок http://www.computerra.ru/88315/tsodkonstruktor-pochemu-modulnyie-data-tsentryi-vskore-zahvatyat-ryinok/

${ }^{14}$ Compass Datacenters' Chris Crosby To Speak At Data Center World And Uptime Institute Symposium In May http://www.compassdatacenters.com/compass-datacenters-chris-crosby-speak-data-center-world-uptime-institutesymposium/ 

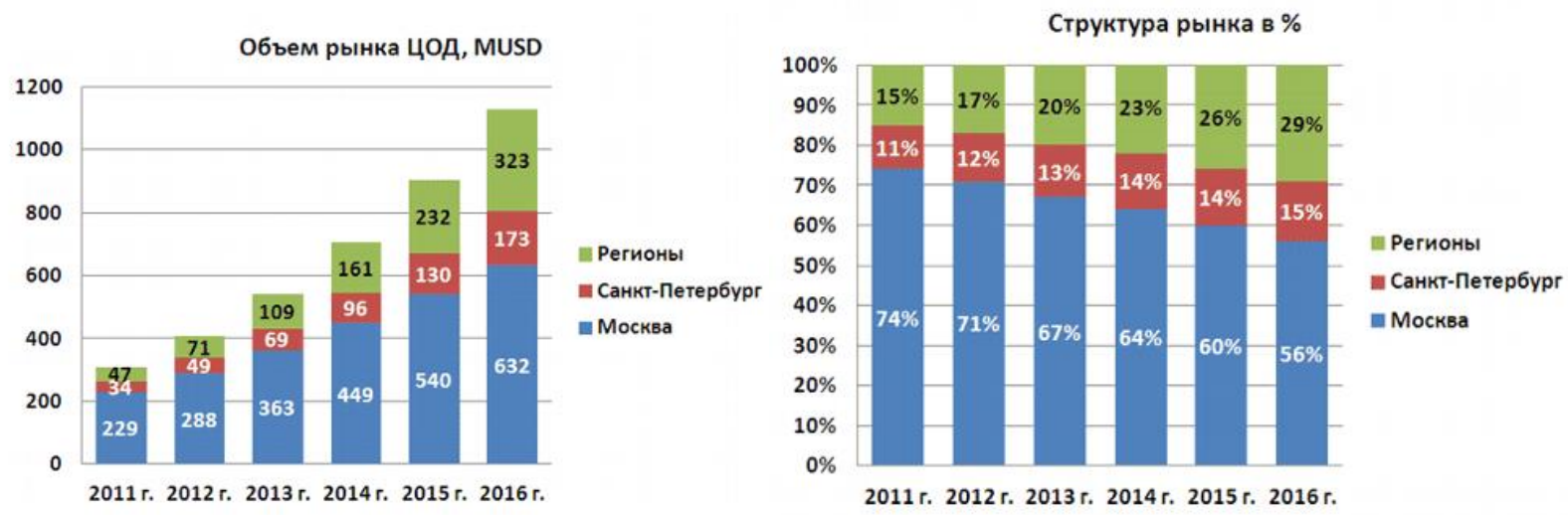

Рисунок 4. Прогноз развития рынка ЦОД по регионам (объем рынка, структура рынка) (Составлено авторами)

Всех участников на российском рынке услуг дата-центров можно условно поделить на четыре группы:

- Корпоративные дата-центры (в первую очередь крупные телекоммуникационные и финансовые компании) - как правило, дата-центры таких компаний ориентированы на удовлетворение внутренних потребностей бизнеса;

- $\quad$ Коммерческие операторы дата-центров - компании, для которых дата-центр является профильным бизнесом, для этих дата-центров характерно значительное преобладание услуги colocation (сдача в аренду мест для размещения клиентского оборудования);

- $\quad$ Крупные системные интеграторы, использующие дата-центр преимущественно с целью предоставления существующим клиентам комплексного решения на основе собственного центра обработки данных[11];

- $\quad$ Телеком-операторы и хостинг-провайдеры - преобладающей услугой является виртуальный хостинг. Подобные компании обладают незначительными или вовсе не имеют собственных дата-центров и целиком или частично размещают свое оборудование на арендуемых технологических площадках коммерческих операторов центров обработки данных[12].

По информации консолидированного консенсус-прогноза прогноза доля площадей коммерческих дата-центров в общем объеме площадей ЦОДов составляет не более $10 \%$. Однако, эта ситуация будет меняться по мере развития рынка, постепенно приближаясь к распределению на уже сформировавшемся рынке США, на котором доля коммерческих операторов составляет всего $37 \%$ (см. рис.5). 


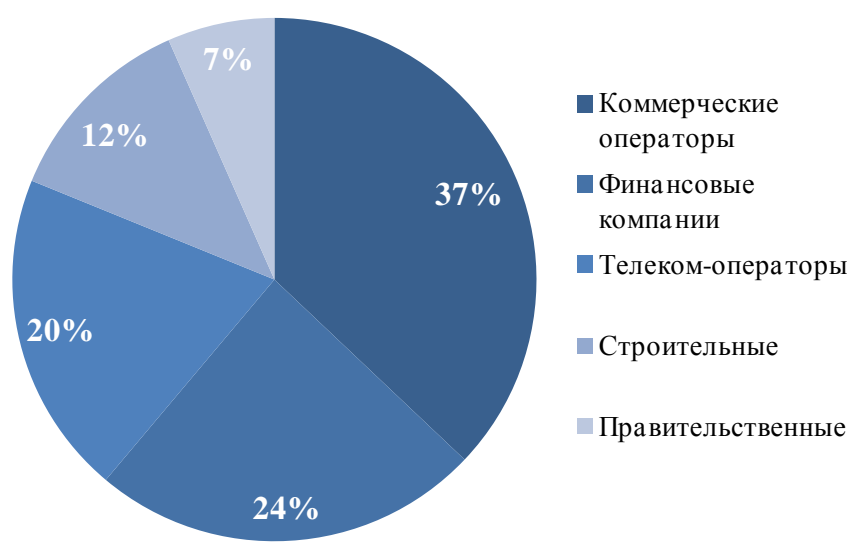

Рисунок 5. Распределение по видам операторов на рынке США. (Составлено авторами)

Далее, рассмотрим текущую емкость российского рынка и рынка Ленинградской области и г. Санкт-Петербурга. Для оценки емкости рынка дата-центров предлагается использовать несколько независимых оценок, основанных на данных как более развитых западных рынков дата-центров, так и прогнозах развития смежных рынков[13]. В качестве основных смежных рынков предлагается рассмотреть:

1. Телекоммуникационный рынок - потребитель collocation, dedicated;

2. Рынок облачных технологий;

3. Рынок ИТ-услуг (внедрение систем хранения и управления данными);

4. Рынок серверного оборудования.

По оценкам компании Gartner ${ }^{15}$ объем рынка дата-центров США составляет около \$33 млрд., а сегмент веб-хостинга и co-location - \$23 млрд. В Европейском Союзе рынок датацентров - около $\$ 40$ млрд, сегмент веб-хостинга и со-location - \$8,6 млрд. Таким образом, отечественные ЦОД по самым оптимистичным оценкам зарабатывают в сто раз меньше западных ( $\$ 0,3$ млрд.). При этом, по оценкам специалистов российский рынок отстает в своем развитии от рынков Европы и США примерно на 5 лет. Для того чтобы учесть при оценке емкости российского рынка различия в уровне развития экономик развитых западных стран, предлагается ввести коэффициент, учитывающий уровень ВВП и представляющий собой отношение объема рынка к объему ВВП страны. Для США при уровне ВВП в 2013г. 16799 млрд. долларов этот показатель составит 0,0018\%, а для Европейского Союза с ВВП в 16894 млрд долларов - 0,0024\%. ВВП России в 2013г. составил 2118 млрд. долл. Таким образом, потенциальная емкость российского рынка ЦОДов может составить около \$5 млрд долл. (175 млрд руб.). По площади дата-центров ситуация та же: российские дата-центры это $0,2 \%$ мирового рынка. По показателю полезной площади ЦОДов Москва уступает Лондону, Парижу, Амстердаму, Люксембургу, Дублину, Мадриду и Цюриху. Экспертная оценка: Майк Сега, коммерческий директор Excellerate ${ }^{16}$ : «По суммарному объему площадей коммерческих ЦОДов Москва на порядок уступает любому другому сопоставимому с Москвой по численности населения городу мира - 20-30 тыс. кв.м. в Москве против 200-300

\footnotetext{
15 Gartner о непрерывности бизнеса: возвращение лидера http://www.securitylab.ru/news/tags/Gartner/

${ }^{16}$ Church Management Software by Excellerate http://www.excellerate.com/products/church-management-software/
} 
тысяч в крупных европейских и североамериканских городах.» Мартин Кэролл, $\mathrm{CBRE}^{17}$ : «Совокупная площадь всех московских ЦОД составляет всего десяую часть от площади датацентров Франкфурта или сравнима, например, с размерами одного лишь американского SuperNAP $\sim 40$ тыс.кв.м.», рис.6.

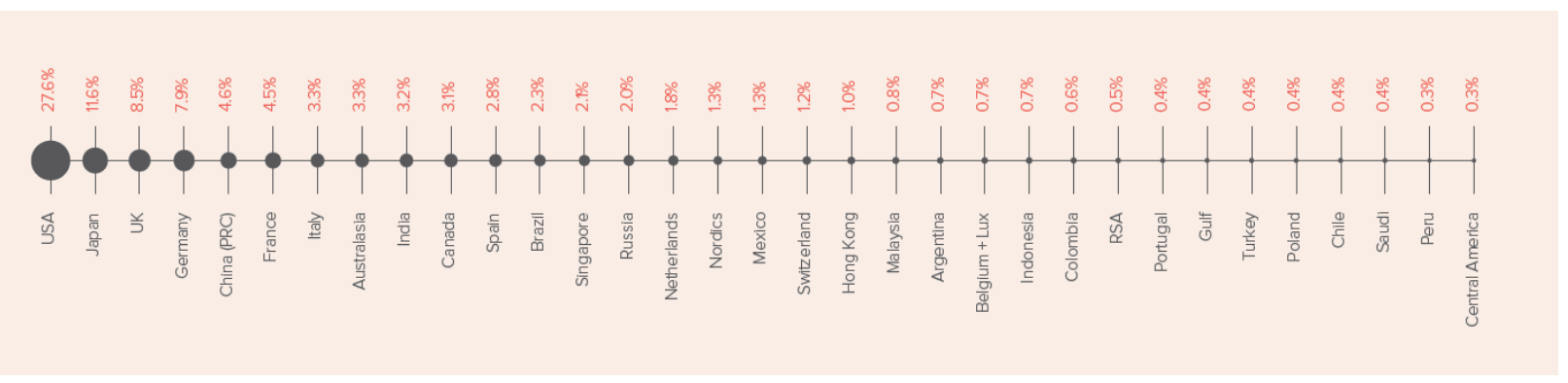

Рисунок 6. Доля стран в общей площади дата-цуентров мира (Составлено авторами)

Таким образом, при достижении зрелости рынка общая площадь дата-центров в России может достигнуть 400-500 тыс.кв.м. Parallels оценивает весь российский рынок облачных технологий в 2013г. в 22,3 млрд.руб., рис.7.

$$
\begin{aligned}
& \text { —aaS } \\
& \text { - SaaS } \\
& \text { веб-присутствие } \\
& \text { веб-приложений }
\end{aligned}
$$

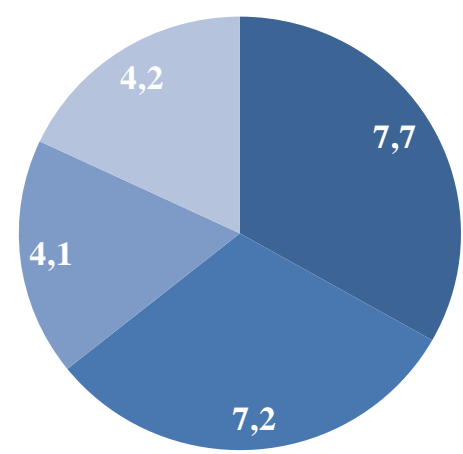

Рисунок 7. Объем рынка облачных технологий по сегментам в 20132. (Составлено авторами)

Оценки других компаний существенно ниже. Orange Business Services ${ }^{18}$ оценила poссийский ынок IaaS в 2012г. в 4,5 млрд.руб. По оценкам компании J'son\&Partners ${ }^{19}$, рынок IaaS в 2011 году в денежном выражении составил 380 млн руб. Общая тенденция развития компьютерных технологий влечет активный рост объема хранимых и обрабатываемых данных. По сведениям компании IDC $^{20}$, темпы ежегодного увеличения объема данных в мире составляют более $80 \%$, при этом затраты на IT возрастают всего лишь на $20 \%$ в год. Согласно оценке других компаний, например Storage Networking Industry Association ${ }^{21}$, за год количество данных в компаниях возрастает на 60\%, и только около $60 \%$ из них расположены в дата-центрах. Директор по стратегии и маркетингу Orange Business Services в России и СНГ Павел Паплински ${ }^{22}$ также считает, что рост рынка облачных услуг является

\footnotetext{
17 Против течения: российский рынок ЦОДов развивается, несмотря на кризис http://www.computerra.ru/93458/protiv-techeniya-kak-rossiyskiy-ryinok-tsodov-razvivaetsya-nesmotrya-na-krizis/ ${ }_{18}$ Orange Business Services в России http://www.orange-business.com/ru

${ }^{19} \mathrm{http}: / /$ www.json.ru/markets_research/new_research/

${ }^{20} \mathrm{http} / / /$ idcrussia.com/ru/research/overview

${ }^{21}$ Storage Networking Industry Association http://en.academic.ru/dic.nsf/enwiki/478787

22 ИТ как средство для развития бизнеса. Обзор рынка системной интеграции в 2012 году http://www.ramec.ru/news/published/693.html
} 
экспоненциальным. Согласно прогнозам этой компании, в России к 2016 г. он вырастет до 19 млрд. руб., тогда как рынок услуг по созданию облачной инфраструктуры составит дополнительно около 20 млрд руб. В агентстве Forrester ${ }^{23}$ считают, что в 2015 году рынок виртуализации может достичь $\$ 500$ млн., увеличившись более чем в десять раз по сравнению c 2011-м. Как следует из доклада президента Parallels Павла Ершова на развивающихся рынках $^{24}$ (см.рис.8), за 2012 год рынок IaaS (инфраструктуры как услуги) вырос на 36\%. В ближайшие годы он будет увеличиваться со среднегодовым темпом в 30\% и к концу 2016 г. достигнет отметки в 17 млрд. руб., рис.8.

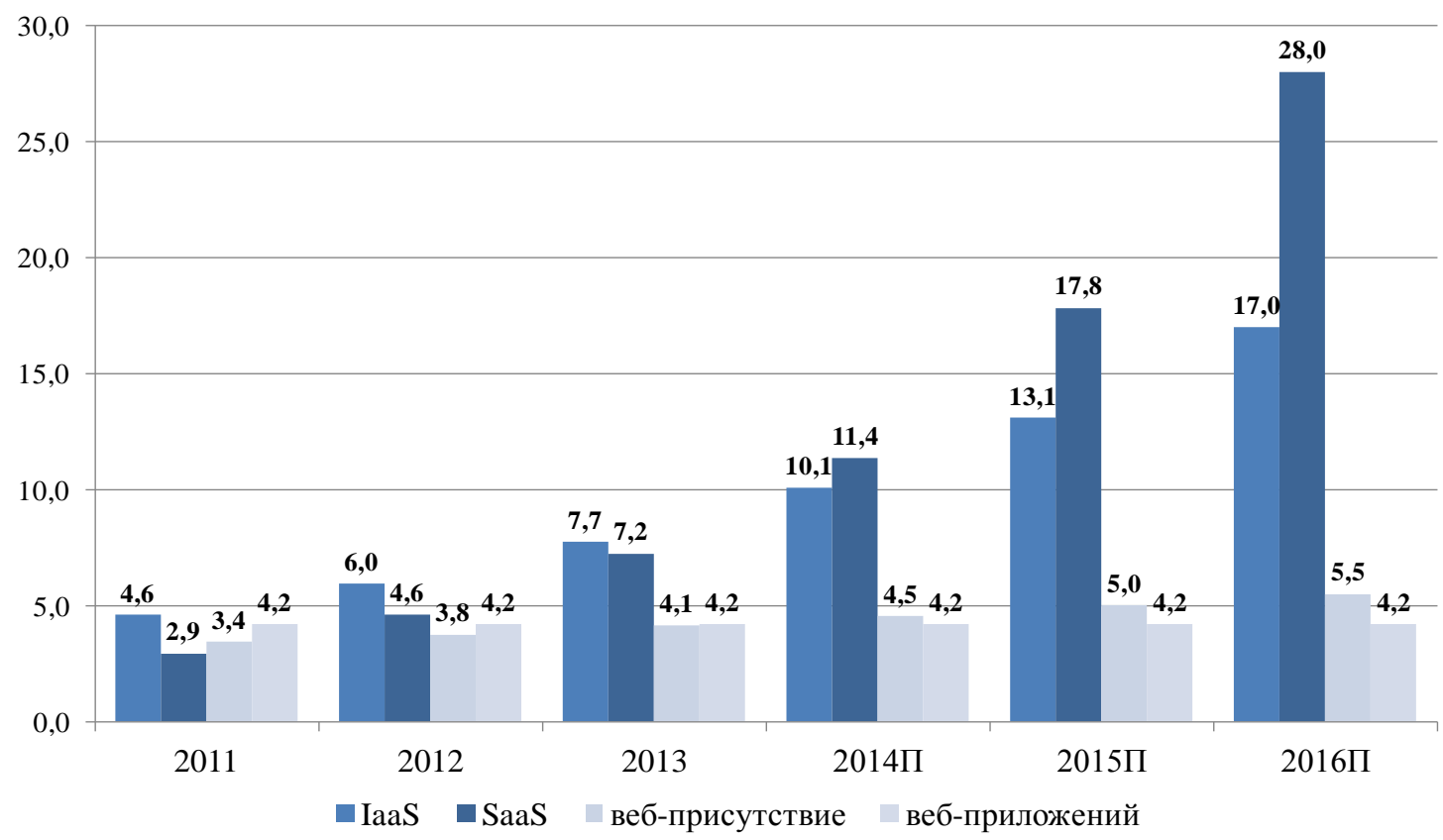

\section{Рисунок 8. Объем рынка облачных технологий по сегментам (Составлено авторами)}

Сегмент SaaS (бизнес-приложений), в свою очередь, может дорасти до 28 млрд руб., демонстрируя средний годовой темп роста в 57\%. Самыми востребованными здесь являются поисковая оптимизация (SEO), управление контентом (CMS) и резервное копирование сайтов. Для рынка веб-присутствия ожидается годовой рост в 10\% — до 5,5 млрд. Интересно, что около 80\% представителей среднего и малого бизнеса не используют автоматизированные телефонные станции (у 17\% нет даже корпоративного телефона), однако $47 \%$ планируют начать использовать виртуальную АТС в ближайшие три года. К 2016 г. сегмент среднего и малого бизнеса (СМБ) увеличится практически в 2,2 раза и достигнет 55,6 млрд. руб., прогнозируют специалисты Parallels. Средневзвешенный рост рынка облачных технологий по прогнозам Parallels составит $\sim 31 \%$ в год. Таким образом, на основании прогнозов роста рынка облачных технологий емкость рынка этого сегмента в выручке дата-центров к 2020г. может составить 25,7 млрд. руб. (при общем объеме выручки 73 млрд. руб.). Все провайдеры телекоммуникационных услуг являются потенциальными пользователями коммерческих ЦОД. По прогнозам аналитиков Gartner ${ }^{25}$, приводящемся в исследовании, мировые расходы на телекоммуникационные услуги в 2012 году выросли на 1\% по сравнению с прошлым годом и

\footnotetext{
${ }^{23}$ Рынок виртуализации России к 2015 году достигнет 0,5 млрд долларов http:/www.rg.ru/2012/01/29/virtul.html 24 "Рынок облачных вычислений в России имеет потенциал роста в десятки раз" - президент по развивающимся рынкам Parallels Павел Ершов http://www.finmarket.ru/interview/?id=2336120

${ }^{25}$ Отчет аналитического агентства Gartner. Рынок «облаков» - прогноз до 2015 года http://habrahabr.ru/company/ActiveCloud/blog/165209/
} 
составят 1,72 триллиона долларов. Российский рынок телекоммуникационных услуг растет большими темпами, чем мировой, считают аналитики iKS-Consulting ${ }^{26}$. В 2013 году он достиг размера 1,635 трлн. рублей, темпы роста составили 6\% против 7\% в 2012 году (см. рис.9).

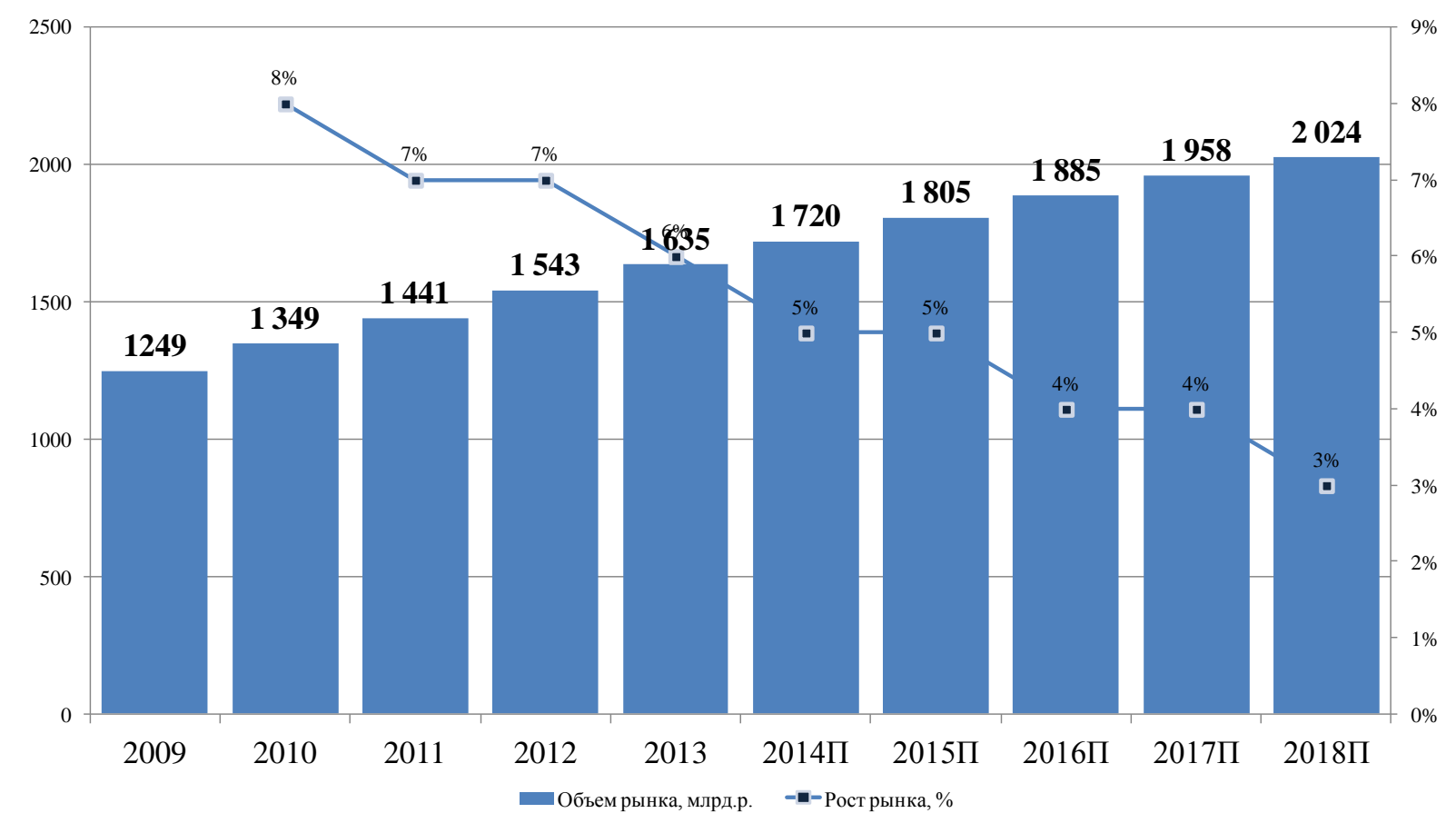

Рисунок 9. Прогноз российского телекоммуникационного рынка до 2018 г.

(Составлено авторами)

Тенденция к снижению динамики продолжится в следующие годы - среднегодовой рост в 2014-2018 годах составит 4\%, - прогнозируют аналитики[12,16]. Низкие темпы роста рынка объясняются исчерпанием источников роста во всех крупнейших сегментах, традиционно являвшихся драйверами рынка. Проникновение сотовой связи в России, по данным исследования iKS-Consulting в 2013г., превысило 166\% по количеству SIM-карт. Количество абонентов широкополосного доступа в интернет превысило 27 млн., проникновение услуги при этом в среднем по стране достигло 49\%. Рынок платного телевидения при проникновении 55\% стремительно замедляет динамику своего развития. Если в 2012 году прирост абонентов составил 17\%, то в 2013 году - лишь 9\%, а в 2014 году ожидается дальнейшее замедление динамики до 6\%. Кроме того, ежегодно в России становится на 0,8-1 млн. меньше абонентов местной телефонной связи, а трафик междугородных и международных звонков продолжает "перетекать" в сети операторов сотовой связи и онлайн-сервисов для общения[6,7].

\footnotetext{
${ }^{26}$ Аналитики iKS-Consulting оценили телеком-рынок Крыма в \$1,8 млрд http://proit.com.ua/news/telecom/2014/04/02/164209.html
} 


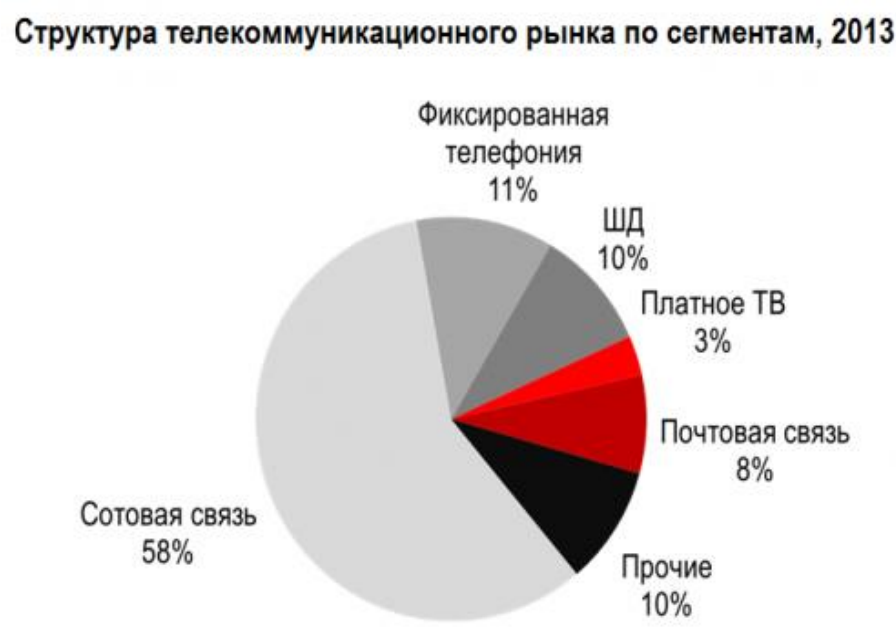

Рисунок 10. Структура российского телекоммуникационного рынка, 20132. (Составлено авторами)

В условиях насыщения крупнейших сегментов рынка, существенных изменений в структуре отрасли не ожидается (см. рис. 10). Более половины доходов приходится на сотовую связь, этот сегмент растет быстрее остального рынка, в основном за счет услуг мобильного интернет-доступа $[1,3]$.

Далее, проанализируем структура спроса телекоммуникационного рынка. Общий объем рынка основных телекоммуникационных услуг в сегменте В2C (Business-to-Consumer) достиг по итогам 2011 года 891 миллиарда рублей. В сегменте В2B (Business to Business, включая микро, малые, средние и крупные предприятия) выручка поставщиков от данных услуг почти в 4,5 раза меньше - 199,6 миллиарда рублей. Государственный сектор B2G (business-to-government) расходует на эти виды услуг 45 миллиардов рублей. Доля частного (потребительского) сегмента в структуре доходов операторов от основных услуг составляет $78 \%$. На В2В рынок приходится $18 \%$ и на государственный сектор $4 \%$, считают аналитики. В настоящее время объем рынка мобильной связи в разы превышает объемы таких услуг как фиксированный доступ в интернет и фиксированная телефония. По итогам 2011 года совокупная выручка операторов мобильной голосовой связи достигла отметки в 767,9 миллиарда рублей, в то время как суммарная выручка операторов интернета и телефонии составила 291,7 миллиарда рублей ${ }^{27}$.

К 2018 г. проникновение платного ТВ в России составит 75\% и охватит 41 млн. абонентов. Проникновение смарт-телевизоров к 2018 г. достигнет 45\%, при этом будет наблюдаться смещение потребления от телевизоров и персональных компьютеров к смартфонам, планшетам и смарт-ТВ. Аналитики также констатируют насыщение рынка сотовой связи и замедление темпов роста фиксированного ШПД и платного ТВ. К 2018 г. “на руках" у российского населения будет 86 млн. смартфонов. Технологией передачи данных LTE через пять лет будет пользоваться $15 \%$ россиян. Россия уже сейчас входит в пятерку ведущих стран по числу абонентов LTE: их уже насчитывается более 0,7 млн. человек. Таким образом, на основании прогнозов роста телекоммуникационного рынка емкость рынка этого сегмента в выручке дата-центров к 2020г. может составить 1,7 млрд руб.

${ }^{27}$ Источник - Digit-обзор, РИА Новости 01.08.2012. 
Согласно результатам исследований $\mathrm{IDC}^{28}$, в 2013 году серверный рынок России сократился на 9,9\% по сравнению с 2012 годом, в поставках - 145233 единиц. Объем рынка в денежном выражении снизился на 29,3\% до $\$ 890,1$ млн. (31,2 млрд. руб.). По мнению аналитиков $\mathrm{IDC}^{29}$, отсутствие роста серверного рынка связано со скромными экономическими успехами страны в 2013 году. Снижение общей деловой активности и невысокий средний уровень использования вычислительных мощностей установленных систем способствовали формированию отложенного спроса на новые серверы $[1,6]$. С учётом прогнозов экономического развития, эволюции программных решений, появления новых серверных платформ и старения парка действующих систем, на рынке серверов России в 2014 году следует ожидать незначительный рост [7, 8]. С другой стороны, провайдеры облачных сервисов и развиваемые ими центры обработки данных окажут большое влияние на рынок инфраструктурных решений. От 25 до 30\% продаж серверов (включая продажи ODMпроизводителей) приходятся на ЦОДы провайдеров сервисов, к 2017 г. этот показатель вырастет до 43\%. При условии, что типовая стойка вмещает в себя 42 сервера, а часто случающиеся у операторов ЦОД ограничения по возможности подачи на стойку мощностей электроэнергии до 4-5 КВт позволяют использовать стойки всего на 30-40\%. Объем монтируемых стоек в 2013г. могло составить порядка 3,5 тыс. Что при средней площади стойки 2,5-3,5 кв. м. означает ввод порядка 10,5 тыс. кв. м. полезных площадей ЦОД. Таким образом, при сохранении текущих объемов ввоза серверов в РФ, объем введенных в эксплуатацию ЦОД может составить около 70 тыс. кв. м. до 2020г. Итого около 140 тыс. кв. м. полезной площади. На основании консолидированного консенсус-прогноза объем рынка датацентров Санкт-Петербурга и Ленинградской области в 2013 году составил 2,1 млрд руб., около 5,5 тыс. стоек или 14 тыс. кв. м. полезной площади ЦОД.

Далее, проведем анализ динамики российского рынка, включая анализ цен и структуры потребления услуг[4,5]. По оценкам DCD-intelligence ${ }^{30}$ объем ввода площадей в 2013г. составил около 45 тыс. кв. м., из них коммерческих операторов - около 4,5 тыс. кв. м. По объемам ввода Россия заняла 5-е место в Европе.

\begin{tabular}{|c|c|c|c|c|}
\hline \multicolumn{5}{|c|}{ Europe } \\
\hline \multicolumn{2}{|l|}{ Rank } & \multirow{2}{*}{\begin{tabular}{|l|}
2012 \\
110 \\
\end{tabular}} & \multirow{2}{*}{$\begin{array}{l}2013 \\
145\end{array}$} & \multirow{2}{*}{\begin{tabular}{|l|}
$\%$ Increase \\
$31.8 \%$ \\
\end{tabular}} \\
\hline 1st & Turkey & & & \\
\hline 2nd & Poland & 115 & 140 & $21.7 \%$ \\
\hline $3 r d$ & Other markets & 160 & 190 & $18.8 \%$ \\
\hline 4th & Nordics & 390 & 440 & $12.8 \%$ \\
\hline 5th & Russia & 605 & 650 & $7.4 \%$ \\
\hline 6th & Switzerland & 360 & 380 & $5.6 \%$ \\
\hline 7th & Germany & 2,450 & 2,550 & $4.1 \%$ \\
\hline 8th & Netherlands & 570 & 590 & $3.5 \%$ \\
\hline 9th & UK & 3,700 & 3,650 & $-1.4 \%$ \\
\hline 10th & France & 1,470 & 1,440 & $-2.0 \%$ \\
\hline 11th & Spain & 920 & 900 & $-2.2 \%$ \\
\hline 12th & Belgium + Lux & 230 & 225 & $-2.2 \%$ \\
\hline 13th & Italy & 1,120 & 1,070 & $-4.5 \%$ \\
\hline & EUROPE & 12,200 & 12,370 & $1.4 \%$ \\
\hline
\end{tabular}

\section{Рисунок 11. Анализ динамики телекоммуникационного рынка (Составлено авторами)}

\footnotetext{
${ }^{28} \mathrm{http} / / /$ idcrussia.com/ru/research/overview

${ }^{29} \mathrm{http} / / /$ idcrussia.com/ru/research/overview

${ }^{30}$ DCD Intelligence to Host Peer-Led Seminar, "Leveraging Data Center Portfolios to Mitigate Risk and Create Strategic Advantage" http://finance.yahoo.com/news/dcd-intelligence-host-peer-led-152625657.html
} 
Темпы ввода стоек и площадей в эксплуатацию оцениваются разными компаниями очень по-разному. Оценки на период после 2013г. варьируются от 22\% в год (iKS-Consulting) до $37 \%$ (HeadWorkAnalytics) ${ }^{31}$. На рис.12 приведен средневзвешенный результат динамики ввода стоек и площадей по рынку ЦОД России и Санкт-Петербурга до 2020г.

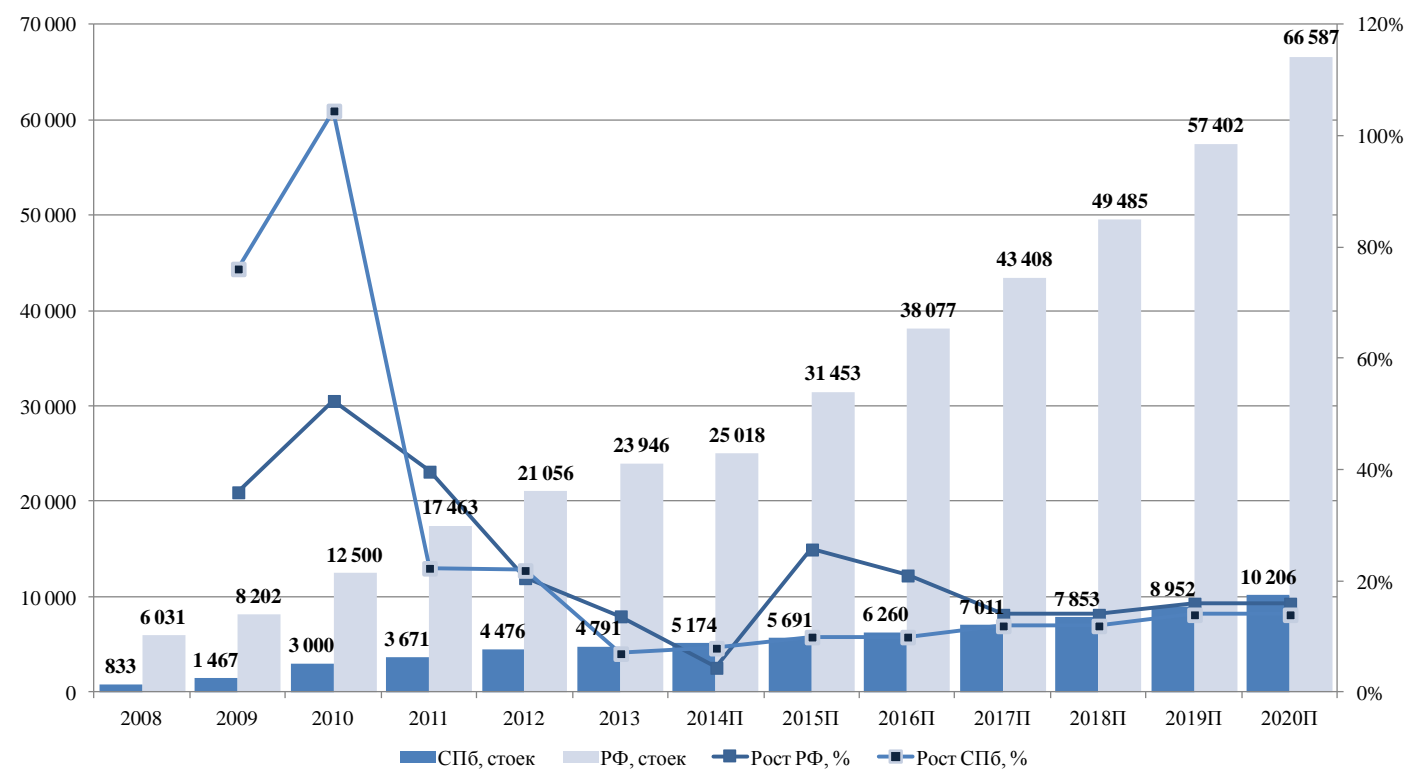

Рисунок 12. Консенсус-прогноз ввода стоек в эксплуатаџию до 20202.

(Составлено авторами)

В 2009 и 2010 годах мировой и российский рынок аутсорсинга ЦОД показал небывалый рост на 40-60\% в год. Причина, названная экспертами, — в трудные экономические времена западные страны заинтересованы в уменьшении капитальных затрат и в повышении сложности среды дата-центров, рис.13.

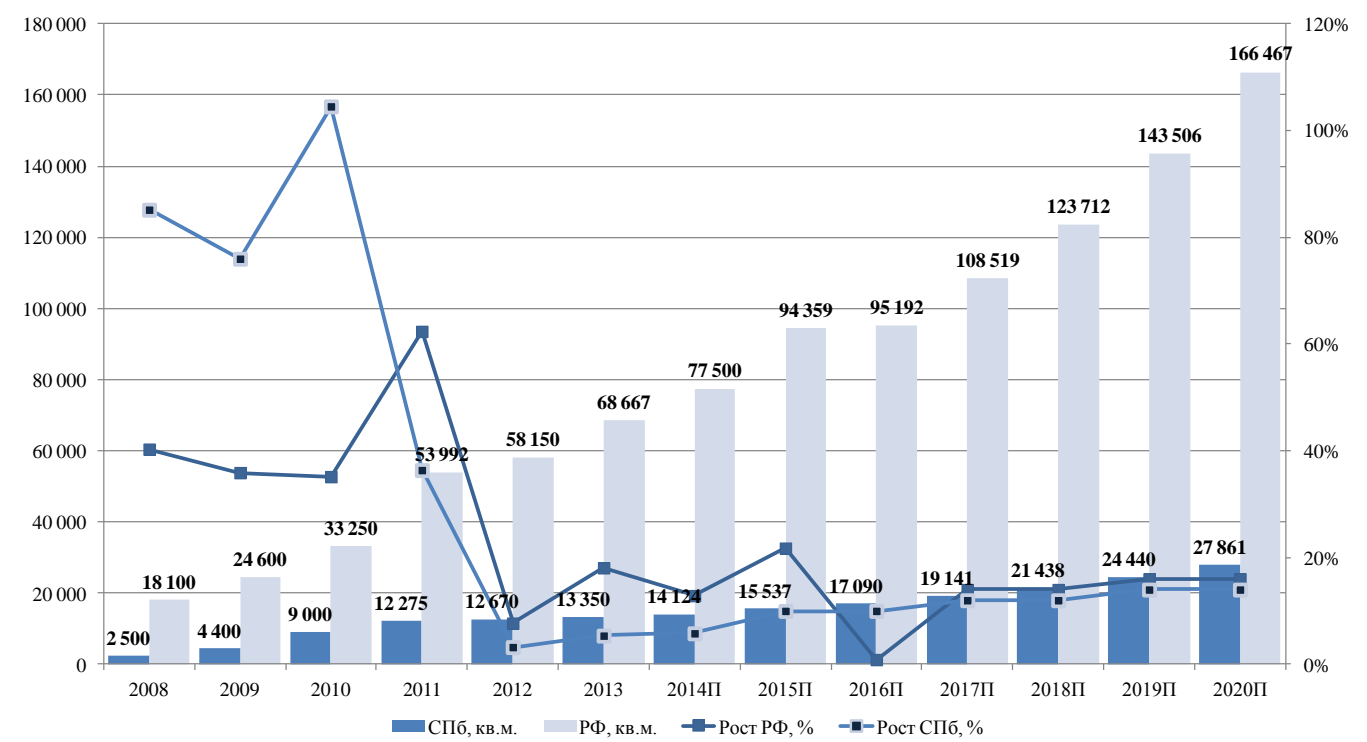

Рисунок 13. Консенсус-прогноз ввода площуадей дата цеентров в эксплуатацию до 20202.

(Составлено авторами)

${ }^{31}$ http://www.headwork.ru/ 
Рынок Санкт-Петербурга: годовой темп прироста в 2013г. по количеству введенных площадей составил около 5\%, что в 3 раза ниже, чем на рынке коммерческих дата-центров Московского региона (Москва и Московская область). Такую ситуацию можно объяснить существенным приростом общего предложения в г. Санкт-Петербурге и Ленинградской области в 2011-2012 гг. и, соответственно, необходимостью его реализации операторами в течение 2012-2013 гг. в условиях «рынка покупателя». Игорь Арнаутов из «Инвесткафе» ${ }^{32}$ предполагает, что рынок ЦОД будет увеличиваться, но все-таки более умеренно, нежели в прошлых периодах. Это происходит, прежде всего, потому, что появляется все больше новых качественных предложений.

Рынок Москвы: по оценке ЗАО «Современные Телекоммуникации» ${ }^{33}$, объявленные на 2013 год планы по вводу новых технологических площадей ЦОД были выполнены всего на 18\%. Завершение значительной части крупных проектов ЦОД перенесено на 2014 год. Далее, проанализируем динамику предложения по объему выручки. Темпы роста российского рынка дата-центров оцениваются разными компаниями очень по-разному. Оценки от 8 компаний на период после 2013г. варьируются от 6\% в год (BroadGroup) ${ }^{34}$ до 44\% (MForum Analytics) ${ }^{35}$, В Диаграмме ниже приведен средневзвешенный результат динамики роста объема выручки по рынку ЦОД до 2016г. Росси и Санкт-Петербурга, рис.14.

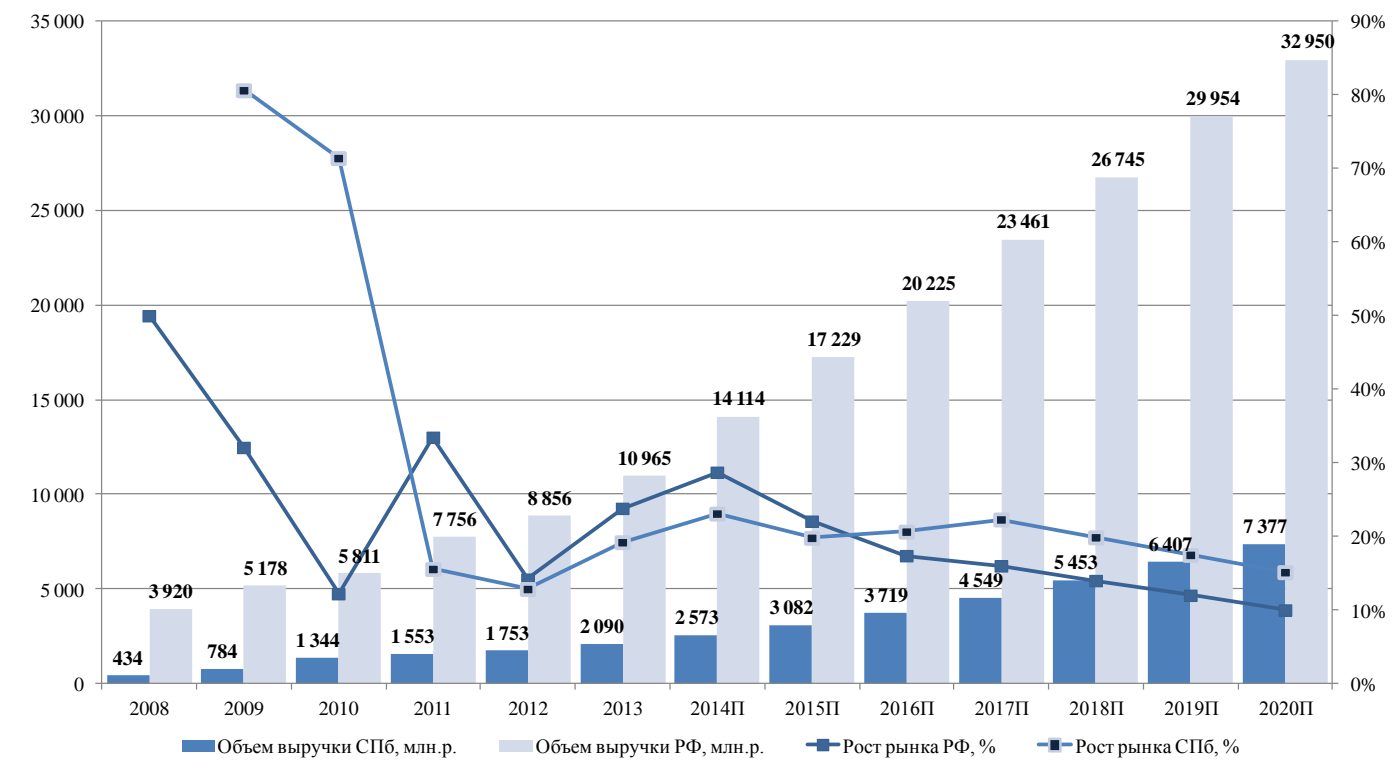

Рисунок 14. Консенсус-прогноз объема выручки до 20202. (Составлено авторами)

${ }^{32}$ http://hl.mailru.su/mcached?q=\%D0\%98\%D0\%B3\%D0\%BE\%D1\%80\%D1\%8C\%20\%D0\%90\%D1\%80\%D0 $\% \mathrm{BD} \% \mathrm{D} 0 \% \mathrm{~B} 0 \% \mathrm{D} 1 \% 83 \% \mathrm{D} 1 \% 82 \% \mathrm{D} 0 \% \mathrm{BE} \% \mathrm{D} 0 \% \mathrm{~B} 2 \% 20 \% \mathrm{D} 0 \% \mathrm{~B} 8 \% \mathrm{D} 0 \% \mathrm{~B} 7 \% 20 \% \mathrm{C} 2 \% \mathrm{AB} \% \mathrm{D} 0 \% 98 \% \mathrm{D} 0 \% \mathrm{BD} \% \mathrm{D} 0$ $\%$ B2\%D0\%B5\%D1\%81\%D1\%82\%D0\%BA\%D0\%B0\%D1\%84\%D0\%B5\%C2\%BB\%20\%20\%20\%D0\%BF\%D1\%80\% D0\%B5\%D0\%B4\%D0\%BF\%D0\%BE\%D0\%BB\%D0\%B0\%D0\%B3\%D0\%B0\%D0\%B5\%D1\%82\%2C\%20\%D1\%87\% D1\%82\%D0\%BE\%20\%D1\%80\%D1\%8B\%D0\%BD\%D0\%BE\%D0\%BA\%20\%D0\%A6\%D0\%9E\%D0\%94\%20\%D0\% B1\%D1\%83\%D0\%B4\%D0\%B5\%D1\%82\%20\%D1\%83\%D0\%B2\%D0\%B5\%D0\%BB\%D0\%B8\%D1\%87\%D0\%B8\%D 0\%B2\%D0\%B0\%D1\%82\%D1\%8C\%D1\%81\%D1\%8F\&c=14-1\%3A39-

$1 \& \mathrm{r}=9047151 \& \mathrm{rch}=1 \& q u r l=h t t p \% 3 \mathrm{~A} / /$ old.iconbit.ru/f/iconbit2.0/press/vk_16_05.pdf\&fr=webhsm

${ }^{33}$ Анализ состояния и тенденций развития рынка телекоммуникационных услуг в Московской области http://www.sotovik.ru/analyt/rinok-telekommunikaciy-moscow.html

${ }^{34}$ BroadGroup запускает исследование Datacentres Europe 5http://telecombloger.ru/tag/broadgroup

35 Рынок центров обработки данных (ЦОД) РФ. Прогноз развития рынка на период 2012-2016 гг http://www.mforum.ru/analit/pubs/101679.htm 
Далее, проанализируем динамику спроса на российском рынке. По заказу Oracle исследовательская компания Quocirca провела осенью 2012 г. 952 телефонных интервью об использовании ЦОДов в 10 регионах, среди которых есть и Россия. Исследование показало рост доли респондентов, использующих только собственные ЦОДы на 19\% - с 45\% до 66\%. При этом доля организаций с единственным собственным дата-центром увеличилась до $41 \%$ (26\% в 2011 г.). Несколько ЦОДов запущены у 25\% (ранее у 19\%). Что касается заказчиков, совмещающих аренду и владение мощностями, то доля таких организаций за год уменьшилась с 56\% до 34\%. Как отмечают в PMR Research ${ }^{36}$, среди услуг, предлагаемых коммерческими ЦОД, по популярности с большим отрывом лидируют размещение серверов и систем хранения. Этим сервисом воспользовались 80\% текущих клиентов и аренда оборудования (dedicated), востребованная среди 48\% заказчиков. Модель SaaS используют менее 20\% крупных клиентов российских дата-центров. (Астерос). Эти показатели зависят, в первую очередь, от продуктовой стратегии дата-центра и варьируются по рынку от 90\% (КРОК) до 60\% (DataLine). На примере одного из активных сегментов потребителей услуг ЦОДов - банковского сектора можно наблюдать, что основная часть расходов на ИТ сформирована за счет обновления/закупки собственного оборудования. Однако, достаточное внимание уделяется и облачным технологиям ( $30 \%$ от опрошенных компанией CNews Analytics), рис.15.

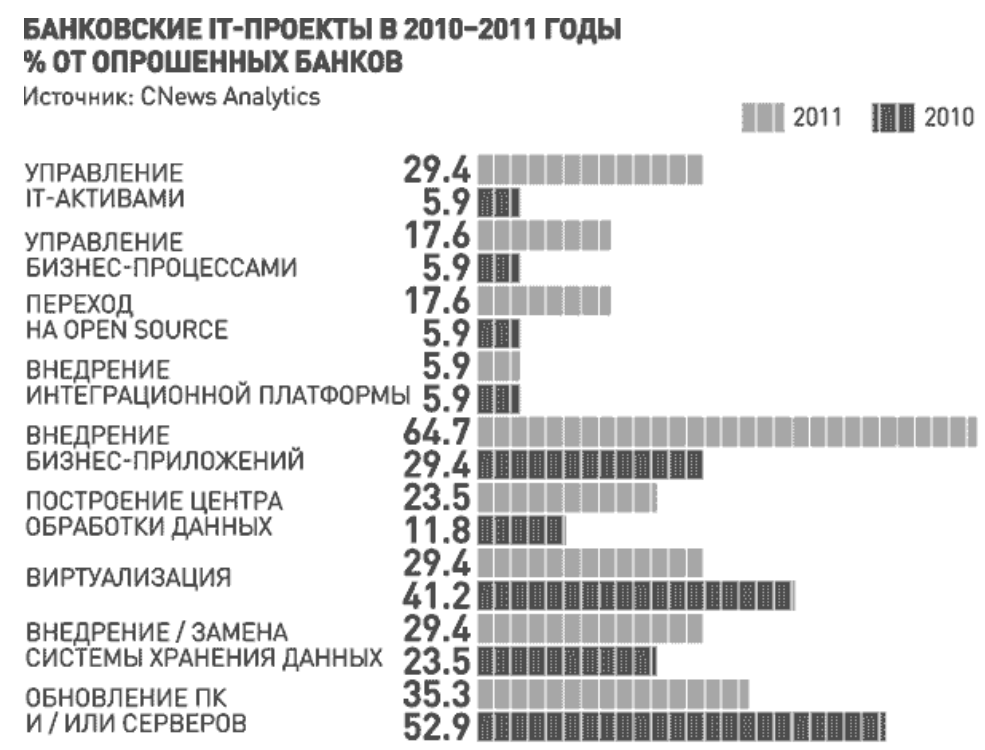

\section{Рисунок 15. Анализ сегментов потребителей услуг ЦОДов - банковского сектора (Составлено авторами)}

По прогнозам аналитической компании MForum Analytics ${ }^{37}$ структура рынка по продуктовым группам будет меняться в пользу увеличения облачных технологий. За счет более высоких темпов роста рынка услуг на базе облачных платформ будет происходить сравнительно быстрое перераспределение рынка - доля облачных услуг вырастет за период 2011-2016 гг. с 13\% до 35\%, доля услуг связи ЦОД - не изменится и составит 9-10\%, доля ITобслуживания - вырастет с $19 \%$ до 23\%, доля Dedicated - снизится $18 \%$ до 9\%, доля Colocation - снизится с $42 \%$ до 24\%, рис. 16.

\footnotetext{
36 PMR: Российский рынок дата-центров сохраняет двузначный рост http://www.osp.ru/news/2013/1129/13022237/

${ }^{37}$ Рынок центров обработки данных (ЦОД) РФ. Прогноз развития рынка на период 2012-2016 гг http://www.mforum.ru/analit/pubs/101679.htm
} 

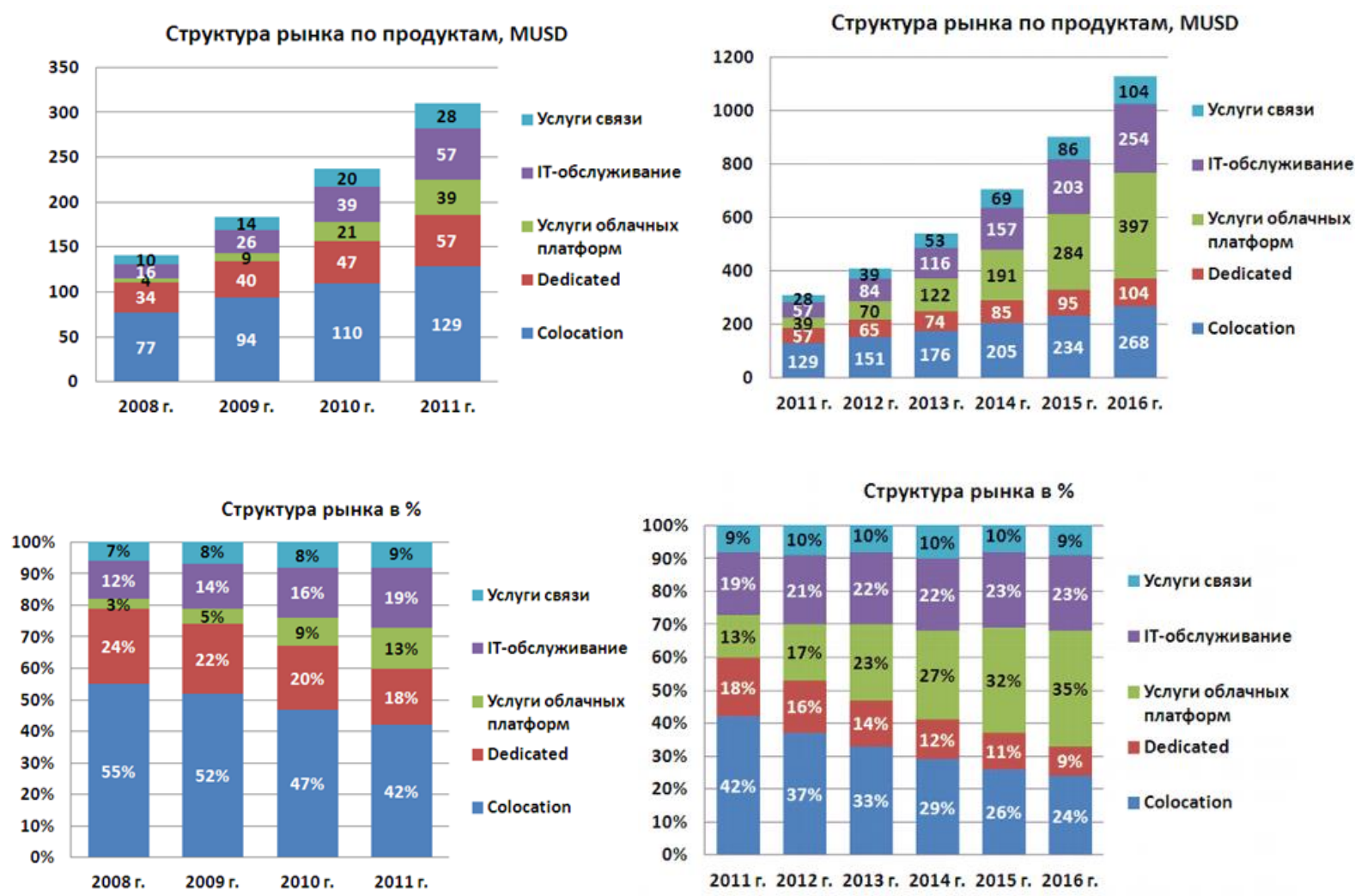

Рисунок 16. Структура рынка по продуктовым группам (Составлено авторами)

Далее, проанализируем спрос в разрезе по объему. ЦОДы вместимостью до 100 стоек наиболее востребованный на рынке формат. Как правило, именно в эту категорию попадают корпоративные ЦОДы крупных финансовых, страховых, телекоммуникационных компаний, а также многие коммерческие ЦОДы. Больше половины всех затрат на колокацию приходится на долю банков, которые пользуются услугами ЦОД для нужд резервного копирования данных и дублирования ИТ-систем. Как правило, банки арендуют площадь для 10-15 стоек. Компании малого и среднего бизнеса (СМБ) обычно арендуют 5-10 стоек. Согласно оценкам владельцев ЦОД, на сегодняшний день около 70\% российских компаний запрашивает до 7кВт на стойку и только 10-15\% обращений с вопросом о размещении оборудования имеют требование до 12-17 кВт на стойку/шкаф. Выбирая между площадками под коммерческий ЦОД при определенном бюджете строительства, необходимо учитывать, что разница в экономической эффективности дата-центра с высоконагруженными и малонагруженными стойками может оказаться не столь большой, а вот спрос на стойки в 10-15-20 кВт еще недостаточно велик, чтобы делать на него ставку.

Далее, проанализируем спрос в разрезе по клиентам. Основными потребителями услуг ЦОД традиционно выступают финансовый рынок (более 40\%), наряду с телекомом, сырьевыми компаниями и органами государственной власти. Другие крупные заказчики -

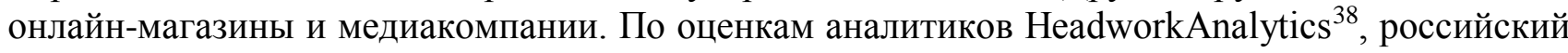
рынок коммерческих дата-центров тем не менее растет на 20-30\% в год: быстрее, чем отрасль ИТ в целом. На долю крупных заказчиков приходится $40 \%$ от общего рыночного спроса, причем наиболее активными потребителями услуг КЦОД являются медиа-холдинги (42\%), транспортные и логистические компании (35\%) и банки (33\%). Ритейл, оптовая торговля,

\footnotetext{
38 Дефицит коммерческих ЦОД к 2015 году достигнет 22\% http://www.osp.ru/resources/focuscenters/cod/news/news_306.html
} 
энергетика и промышленность демонстрируют умеренный интерес. Нефтегазовые компании и негосударственные пенсионные фонды потребности в услугах коммерческих ЦОД пока не испытывают. Сегмент малого и среднего рынка (SMB) остается не таким активным, хотя эксперты полагают, что правильные услуги и развитие рынка дадут со временем мощный импульс к росту услуг ЦОД именно в этом секторе. Компании малого и среднего бизнеса обычно приобретают выделенные серверы, в том числе виртуальные, для хостинга сайтов, приложений и баз данных. (PMR Research). Малый и средний бизнес менее активен - как ожидается, в этом сегменте спрос на услуги КЦОД будет расти лишь на 10-15\% в год. Но и в этом сегменте заказчики все реже ограничиваются потреблением простых услуг, таких как хостинг почтовой системы, и постепенно расширяют спектр востребованных сервисов. (HeadworkAnalytics). Упоминания ключевых групп клиентов некоторыми провайдерами приведены в таблице 2 ниже.

Таблица 2

Рейтинг сегментов клиентов операторов ЦОД

\begin{tabular}{|c|c|c|c|c|c|c|}
\hline Компании & VMware & ТрастИнфо & DataLine & КРОК & ENSPACE & $\begin{array}{c}\mathbf{X X X} \\
\text { Телеком }\end{array}$ \\
\hline Финансовые компании & 2 & & 1 & 1 & & 1 \\
\hline Телеком-операторы & & & & & & 2 \\
\hline Интернет-компании & 1 & & & & & \\
\hline Ритейл & & & 2 & & 2 & \\
\hline Медиа-холдинги & & & 3 & & 3 & \\
\hline Крупные компании & & 2 & & & & \\
\hline Средний и малый бизнес & & 1 & & & 1 & \\
\hline
\end{tabular}

Источник: экспертные интервью с представителями (Составлено авторами)

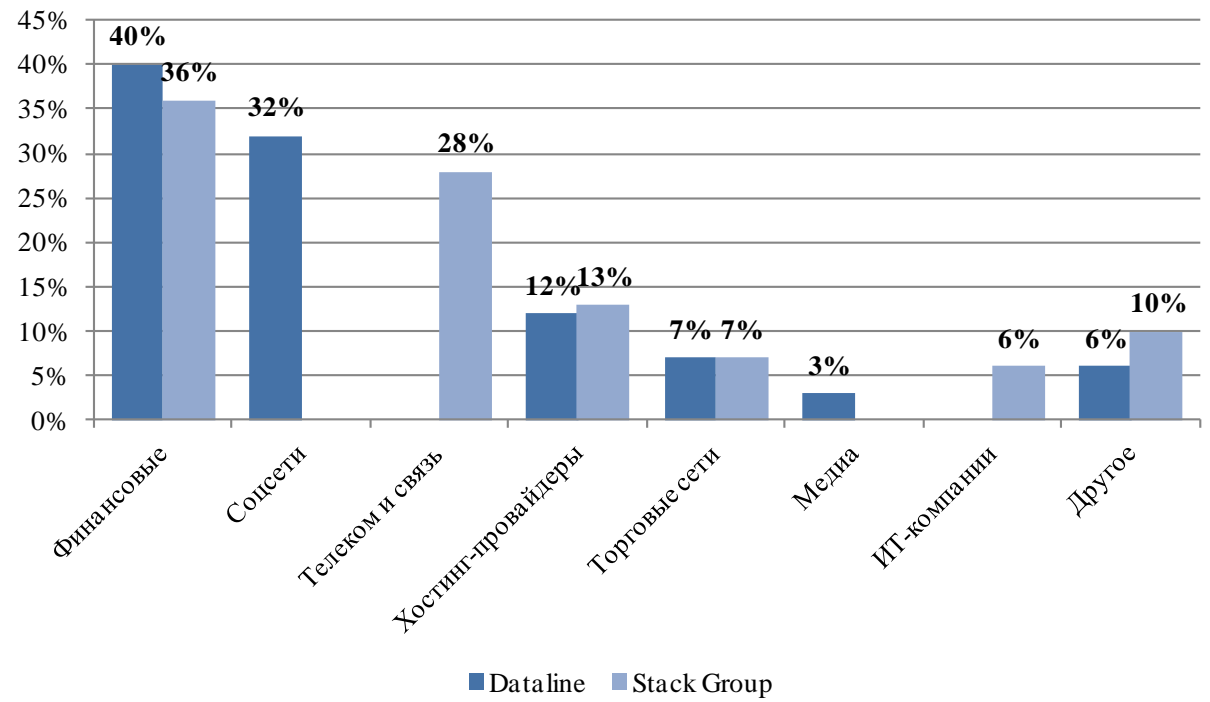

Источник: экспертные интервью с представителями

Рисунок 17. Структура клиентов операторов ЦОД (Составлено авторами) 
Далее, проанализируем спрос на рынке Санкт-Петербурга. По мнению экспертов ТК «Миран» ${ }^{39}$, наиболее активными компаниями, размещающими свое оборудование в датацентрах в Санкт-Петербурге остаются ИТ-компании, также увеличивается количество различных финансовых организаций, для которых наиболее важна сохранность и конфиденциальность данных.

Таблица 3

Топ-10 компаний, размещающих оборудование в дата-центрах СПб

\begin{tabular}{|c|l|}
\hline 1 & Хостинговые компании \\
\hline 2 & Крупные Интернет-проекты (социальные сети и пр.) \\
\hline 3 & Телекоммуникационные компании \\
\hline 4 & Институты и исследовательские компании (для себя) \\
\hline 5 & Контент-провайдеры \\
\hline 6 & Банки и страховые компании \\
\hline 7 & $\begin{array}{l}\text { Крупные софтверные компании с непрерывным циклом оказания услуг (биллин- } \\
\text { говые компании) }\end{array}$ \\
\hline 8 & Торговые сети, бутики \\
\hline 9 & Крупные корпорации с большой территориально распределенной филиальной сетью \\
\hline 10 & Агентства недвижимости \\
\hline
\end{tabular}

(Составлено авторами)

Далее, проанализируем динамику инвестиций на российском рынке. Глобальное исследование компании DCD Intelligence показало ${ }^{40}$, что в российский рынок в 2013г. было инвестировано порядка \$3,58 млн.долл., что больше на 9\% чем в 2012г. Рост инвестиций в ЦОДы в 2012 году составил 22,1\% по сравнению с уровнем 2011 года: с \$86 млрд до \$105 млрд. Для сравнения, инвестиции в США выросли в 2013г. на 6\%. Лидерами роста инвестиций в 2013г. в Европе стали Польша - 43\%, Турция - 27\%.

\begin{tabular}{|c|c|c|c|c|}
\hline \multicolumn{2}{|c|}{ Rank } & \multirow{2}{*}{$\begin{array}{l}2012 \\
0.74 \\
\end{array}$} & \multirow{2}{*}{\begin{tabular}{|l|}
2013 \\
1.06 \\
\end{tabular}} & \multirow{2}{*}{\begin{tabular}{|l|}
$\%$ Increase \\
$43.2 \%$ \\
\end{tabular}} \\
\hline 1st & Poland & & & \\
\hline 2nd & Other markets & 0.5 & 0.7 & $40.0 \%$ \\
\hline $3 r d$ & Turkey & 0.75 & 0.95 & $26.7 \%$ \\
\hline 4th & Nordics & 1.35 & 1.58 & $17.0 \%$ \\
\hline 5th & Russia & 3.28 & 3.58 & $9.1 \%$ \\
\hline 6th & Netherlands & 2.9 & 3.15 & $8.6 \%$ \\
\hline 7th & Switzerland & 1.49 & 1.6 & $7.4 \%$ \\
\hline 8th & Germany & 7.8 & 8.3 & $6.4 \%$ \\
\hline 9th & France & 5.71 & 6 & $5.1 \%$ \\
\hline 10th & Belgium + Lux & 1.39 & 1.45 & $4.3 \%$ \\
\hline 11th & UK & 15 & 15.5 & $3.3 \%$ \\
\hline 12th & Spain & 2.5 & 2.45 & $-2.0 \%$ \\
\hline 13th & Italy & 2.05 & 1.95 & $-4.9 \%$ \\
\hline & EUROPE & 45.46 & 48.27 & $6.2 \%$ \\
\hline
\end{tabular}

Рисунок 18. Динамика инвестиичий на рынке ЦОД (Составлено авторами)

\footnotetext{
${ }^{39}$ Рынок ЦОДов набирает обороты http://portal.inno-club.ru/?q=node/354

${ }^{40}$ DCD Intelligence to Host Peer-Led Seminar, "Leveraging Data Center Portfolios to Mitigate Risk and Create Strategic Advantage" http://finance.yahoo.com/news/dcd-intelligence-host-peer-led-152625657.html
} 
Далее, проанализируем прогнозные цены на услуги аренды стоек. Дефицит качественного предложения в Москве и РФ позволяет держаться высоким ценам на аренду стойки и юнита в ЦОДах класса выше Tier III. В целом, на конечной цене для потребителя услуг ЦОД уровня Tier III и выше все перечисленные факторы отражаются следующим образом: по экспертной оценке, средняя цена стойки у лидеров рынка в РФ варьируется в диапазоне 47-105 тыс. рублей за 5 кВт стойку (включая НДС). Журнал «ЦОДы.РФ» ${ }^{41}$ провел опрос в 2013г. среди владельцев коммерческих дата-центров. Респондентами выступили представители руководящего звена 70 компаний, рис. 19.
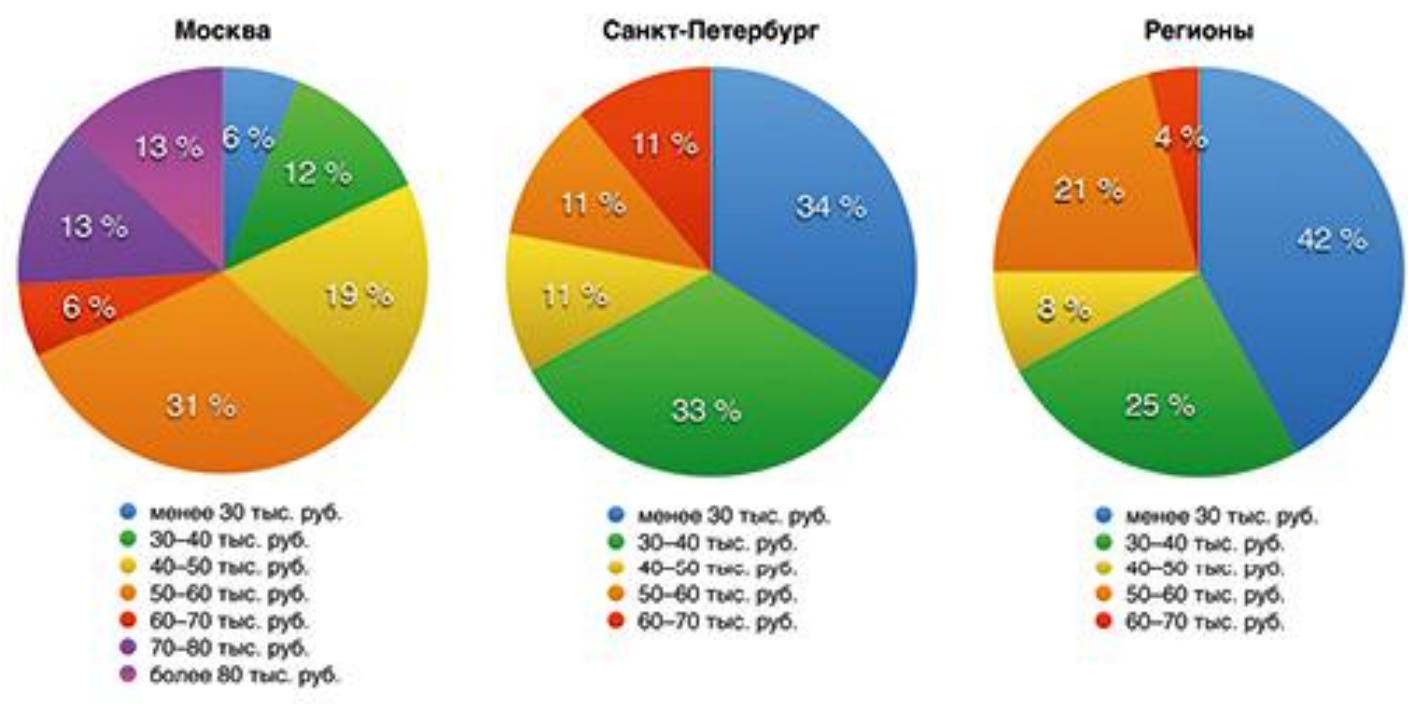

Рисунок 19. Средняя стоимость одной стойки мощчностью 5 кВт (Составлено авторами)

Цены в Москве выше средней по РФ. В Москве сконцентрированы все предложения в высоком ценовом сегменте выше 70 тыс.р. за стойку ( 26\% от всего объема). Это предложения высокого качества (со стандартом ЦОД выше Tier III).

Таблица 4

\section{Стоимость аренды 1 стойки $42 \mathrm{U}$ в Москве}

\begin{tabular}{|l|c|}
\hline \multicolumn{1}{|c|}{ Услуга } & Цена с НДС \\
\hline TIER III & $80-150$ тыс. руб. \\
\hline TIER II & $55-80$ тыс. руб. \\
\hline TIER I & $47-55$ тыс. руб. \\
\hline
\end{tabular}

(Составлено авторами)

В 2011-2012 г.г. стоимость предоставления услуги аренда юнита и прочих небольших услуг снизилась в связи с выходом на рынок большого количества мини и микро - ЦОДов, предоставляющих услуги низкого качества (ниже стандарта TIER I). Конкурентная борьба сопровождается агрессивными маркетинговыми акциями, такими как скидки в 20-50\% на срок 3-6 месяцев и предложение потенциальным клиентам сниженных тарифов за уход от других операторов. PMR Research. Одной из составляющих ценообразования в коллокейшн является взимание инсталляционного платежа, рис. 20.

\footnotetext{
${ }^{41}$ http://www.цоды.pф/
} 

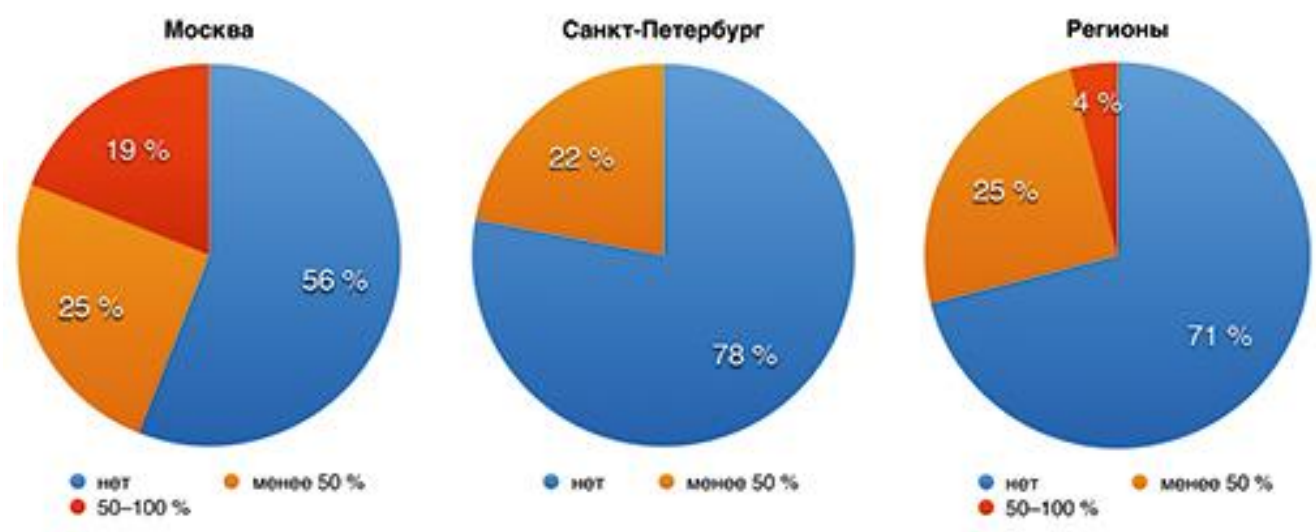

Рисунок 20. Доля компаний использующих инсталлящионный платеж в \% от арендной платы (Составлено авторами)

Большинство (>70\%) компаний в Санкт-Петербурге и регионах не используют инсталляционный платеж. Немалый инсталляционный платеж в Москве (44 \%, из них 19 \% требуют до $100 \%$ месячной арендной платы) можно объяснить классом (надежностью) большим количеством профессиональных ЦОД высокого стандарта. Следует отметить, что несмотря на бытующее мнение о более дешевых услугах у зарубежных провайдеров, цены на размещение $1 \mathrm{U}$ с портом 100 Мбит/с в Москве и в зарубежных дата-центрах примерно равны.

Россия:

- « «версан-Луна»-2980 рублей/месяц;

- $\quad$ TELHosting - 2300 рублей/месяц;

- $\quad$ E-StyleTelecom - 4838 рублей/месяц;

- $\quad$ Agava - 2399 рублей/месяц;

- $\quad$ MSM - 2600 рублей/месяц.

Зарубежье:

- $\quad$ LeaseWeb - 49 Евро/месяц (включен 1 Тб, далее по 10 Евро за 1 Тб);

- $\quad$ Hetzner - 39 Евро в месяц (включено 5 Тб, далее по 6,9 Евро за 1 Тб; 50 Вт электроэнергии, далее по 0, 2975 за 1 Вт);

- $\quad$ Hivelocity - $\$ 99 /$ месяц (включено 500 Гб);

- $\quad$ Superb - \$99/месяц (включено 4 Тб, далее по \$95 за 1 Тб);

- $\quad$ Reliable Servers - \$149/месяц (включено 10 Тб).

По данным PMR Research одна из главных тенденций рынка - падение цен на традиционную колокацию, что заставляет операторов ЦОД инвестировать в более прибыльные предложения, включая виртуальные выделенные серверы, облачные вычисления и управляемые услуги $[7,10]$.

Далее, проанализируем Рынок Санкт-Петербурга. После небольшого снижения в 20112012 г.г. цены на услуги дата-центров в 2013 году в Санкт-Петербурге остались практически неизменны с 2012 года. Несмотря на рост стоимости электроэнергии и повышения стоимости аренды, предпосылок к значительному росту цен на услуги дата-центров не наблюдается. Напротив, в течение всего года можно ожидать появления различных акций, подразумевающих получение дополнительных бонусов для клиента при размещении в дата центре. В настоящее время стоимость размещения оборудование в зависимости от уровня надежности дата-центра находится в следующих границах: от стоимости стойки 42U/5 квт. в 30-40 тыс. рублей для TIER I до 70-90 тыс. рублей для TIER IV. Аналитики «Миран» 
считают $^{42}$, что услуги ДЦ будут пользоваться популярностью, однако в связи с растущим предложением стоимость данных сервисов постепенно станет уменьшаться. Сегодня цена на аренду одного юнита составляет 1,5-2,5 тысячи рублей/месс, табл.5.

Таблица 5

Топ-7 самых востребованных услуг и их стоимость в Санкт-Петербурге

\begin{tabular}{|l|c|}
\hline \multicolumn{1}{|c|}{ Услуга } & Цена с НДС \\
\hline Аренда серверной стойки & $30-90$ тыс. руб. \\
\hline Аренда юнита (colocation) & $1,5-2,5$ тыс. руб. \\
\hline Аренда физического сервера (dedicated) & $3-20$ тыс. руб. \\
\hline Аренда виртуального сервера (vds/vps) & $0,5-7$ тыс. руб. \\
\hline Резервное копирование данных & $0,5-20$ тыс. руб. \\
\hline Аренда приложений & от 1 тыс. руб. \\
\hline Хостинг & $0,5-2$ тыс. руб. \\
\hline
\end{tabular}

(Составлено авторами)

В настоящее время стоимость размещения оборудование в зависимости от уровня надежности дата-центра находится в следующих границах, табл.6:

Таблица 6

\section{Стоимость аренды 1 стойки $42 \mathrm{U}$ в Санкт-Петербурге}

\begin{tabular}{|l|c|}
\hline \multicolumn{1}{|c|}{ Услуга } & Цена с НДС \\
\hline TIER III & $40-80$ тыс. руб. \\
\hline TIER II & $30-50$ тыс. pуб. \\
\hline TIER I & $20-40$ тыс. pуб. \\
\hline
\end{tabular}

(Составлено авторами)

Для компаний класса SMB с 30 сотрудниками и стандартным набором бизнесприложений (бухгалтерия, электронная почта, склад, CRM и т.п.) использование в течение года сервисов IaaS и SaaS облачных провайдеров обойдется почти вдвое дешевле создания собственного миниЦОДа. На основании проанализированного материала можно сделать вывод о том, что на рынке Дата-центров превалируют следующие тенденции:

- Количество дата-центров на рынке будет увеличиваться, причем возможно появление крупных ЦОД.

- $\quad$ Рынок коммерческих дата-центров развивается, будет увеличиваться набор услуг и повышаться их качество, уменьшаться время реакции на запросы, организацию оригинальных акций для арендаторов.

- Относительно новые услуги, такие как аренда приложений, облачные вычисления еще не проникли на массовый рынок. В ближайшие несколько лет спрос на услуги, связанные с арендой вычислительных мощностей в датацентрах, будет возрастать. В настоящее время основными заказчиками подобной услуги выступают фирмы, занимающиеся web-программированием, web-дизайном, разработкой Интернет-приложений, on-line игр и тд., а так же компании, у которых собственные корпоративные сервера которых нуждаются в обновлении.

\footnotetext{
${ }^{42}$ Рынок ЦОДов набирает обороты http://portal.inno-club.ru/?q=node/354
} 
- Существует небольшое количество заказов по аренде вычислительных мощностей для "1C", но с появлением новой версии программы количество обращений увеличивается. Рынок подобных услуг сейчас развивается, и есть вероятность, что он станет массовым.

\section{ЛИТЕРАТУРА}

1. Научно-техническое развитие как инновационный фактор экономического роста. [Текст]: Коллективная монография. /Ашалян Л.Н., Женжебир В.Н., Колосова Г.М., Медведев В.М., Паластина И.П., Положенцева И.В., Пшава Т.С., Фадеев А.С., Филатов В.В., Филатов А.В. Издательство: ЦНТБ Пищевой промышленности, Москва: [б. и.], 2014. - 446 с.

2. Региональные аспекты управления ипотечными кредитными рынками в субъектах РФ и муниципальных образованиях. [Текст]: Коллективная монография. / Филатов В.В., Третьяк А.В., Князев В.В., Кобулов Б.А., Колосова Г.М., Шестов А.В. Издательство: ЦНТБ Пищевой промышленности, Москва: [б. и.], 2014. - 522 с.

3. Роль международных платежных систем в экономике России [Текст]: Коллективная монография. / Филатов В.В., Трифонов Р. Н., Князев В.В., Кобулов Б.А., Положенцева И.В., Шестов А.В. Издательство: ЦНТБ Пищевой промышленности, Москва: [б. и.], 2014. - 462с.

4. Совершенствование стратегического управления предприятия на основе ситуационного анализа и сбалансированной системы показателей. [Текст]: Коллективная монография. /Филатов В.В., Диброва Ж.Н., Медведев В.М., Женжебир В.Н., Князев В.В., Кобулов Б.А., Паластина И.П., Положенцева И.В., Кобиашвили Н.А., Фадеев А.С., Шестов А.В. Издательство: ЦНТБ Пищевой промышленности, Москва: [б. и.], 2015. - 482 с.

5. Управление лицензионной деятельностью: вопросы теории и практики. [Текст]: Коллективная монография. / Ашалян Л.Н., Дадугин М.В., Диброва Ж.Н. Женжебир В.Н., Колосова Г.М., Медведев В.М., Пшава Т.С., Фадеев А.С., Филатов В.В., Филатов А.В. Издательство: ЦНТБ Пищевой промышленности, Москва: [б. и.], 2013. - 417 с.

6. Управление хозяйственными связями предприятия с поставщиками и потребителями [Текст]: Коллективная монография. / Филатов В.В., Мамедов Ф.А., Медведев В.М., Князев В.В., Кобулов Б.А., Фадеев А.С., Шестов А.В., Издательство: ЦНТБ Пищевой промышленности, Москва: [б. и.], 2015.

7. Управление стратегией инвестиционно - экономического развития вертикальноинтегрированного холдинга [Текст]: Коллективная монография. /Филатов В.В., Трифонов Р.Н., Подлесная Л.В., Борисова Т.А., Медведев В.М., Князев В.В., Фадеев А.С., Шестов А.В. Издательство: ЦНТБ Пищевой промышленности, Москва: [б. и.], 2015.

8. Управление стоимостью товарного знака как объекта оценки в целях его коммерциализации [Текст]: Коллективная монография. / Филатов В.В., Князев В.В., Кобулов Б.А., Шестов А.В. Издательство: ЦНТБ Пищевой промышленности, Москва: [б. и.], 2015. 
9. Филатов В.В., Паластина И.П., Дадугин М.В., Нурмагомедова Н.В., Сафронов Б.И. Анализ систем управления стоимостью бизнеса на основе современных информационных технологий. Научно-теоретический журнал «Вопросы гуманитарных наук» - Выпуск №2(52), Издательство «Спутник+», 2011 - С.2126.

10. Медведева Т.Ю., Хомутинникова Т.В., Филатов В.В. Управление технологическими инновациями в АПК на основе создания и развития информационно - консультационных систем. // Мат.-лы Международной научно-практической конференции «Инновационная политика хозяйствующего субъекта: цели, проблемы, пути совершенствования»., секция: «Концептуальные особенности современного менеджмента», М.:МВЦ «Крокус - Экспо», РУДН, 2011, C.496-503.

11. Деева В.А., Филатов В.В., Актуальные вопросы перехода региональной экономики РФ на инновационный путь развития в условиях современной информационной среды. //Мат.-лы VIII Международной научной конференции «Образование, экономика, право в современном информационном обществе», Часть III. М.: Московский Университет им. С.Ю. Витте, 2012 - С.136-142.

12. Филатов В.В., Елисеева Т.В. Анализ национальной инновационной системы РФ на основе стратегической концепции социально-экономического развития регионов в условиях современной информационной среды. //Мат.-лы VIII Международной научной конференции «Образование, экономика, право в современном информационном обществе», Часть III. М.: Московский Университет им. С.Ю. Витте, 2012- С.231-238.

13. Филатов В.В. Новая парадигма пространственной организации инновационной экономики РФ в условиях нарастающей глобализации и современной информационной среды. Мат.-лы II Международной научно-практической конференции «Евразийское пространство: приоритеты социальноэкономического развития», М.:ЕОИ, 2012 - С.623-632.

14. Филатов В.В., Кобулова А.Б. Информационные технологии управления проектным инновационным циклом. VIII-я Международная научнопрактическая конференция, посвященная 125-летию основания г. Унеча «Теория и практика стратегического планирования развития инфра-структуры муниципальных образований», Сборник научных трудов, Том 2 - С.116-133, 2012.

15. Филатов В.В., Карасев М.В. Влияние информационно-коммуникационных технологий на современные методы управления, основанные на экономической оптимизации инноваций. // Материалы международной научно-практической конференции «Достижения науки за последние годы. Новые наработки|Postepy w nauce w ostatnich latach. Nowych rozwiazan.» Варшава|Warszawa, Польша। Poland: Издательская группа \Publishing group «Diamond trading tour», 2012, C.48-60.

16. Карасев М.В., Филатов В.В., Совершенствование стратегического управления инновационными проектами предприятия на основе современных экономикоматематических методов в условиях информационной среды и нарастающей глобализации //Научно - практический журнал «Качество. Инновации. Образование» №1, 2013, С.35-50. 
17. Филатов В.В., Дадугин М.В. Региональные аспекты управления информационно-экономическим развитием современных инновационных предприятий на основе внедрения системы контроллинга. // Теоретический и научно - методический журнал «Вестник Университета», № 14, 2012, С.141-149.

18. Информационное обеспечение и форсайтные исследования инновационной деятельности предприятий. Колосова Г.М., Денисова Н.А., Ашалян Л.Н., Филатов В.В. // Теоретический и научно - методический журнал «Вестник Университета», № 13, 2012, С.17-25.

Рецензент: Рукина И.М. Академик РАЕН, Доктор Экономических наук, профессор, декан факультета управления крупными городами АНО ВПОА «Международный университет в Москве». 
Filatov Vladimir Vladimirovich

Moscow State University of technologies and management by K. G. Razumovsky

Russia, Moscow

E-mail: filatov_vl@mail.ru

Borisova Tatiana Aleksandrovna

Moscow State University of technologies and management by K. G. Razumovsky

Russia, Moscow

E-mail: borgurin@mail.ru

Medvedev Vladimir Mikhailovich

Moscow aviation Institute (national research University)

Russia, Moscow

E-mail:km@mgutm.ru

Shestov Andrey Vladimirovich

Moscow State University of technologies and management by K. G. Razumovsky

Russia, Moscow

E-mail: av2018@mail.ru

Fadeev Aleksandr Sergeevich

Moscow State Technical University by Bauman

Russia, Moscow

E-mail:km@mgutm.ru

\title{
Forecasts and key trends of the global market IT
}

\begin{abstract}
This article explored key trends and conducted the forecasts of the global market IT. This paper analyzes the key trends, qualitatively changing the development of the market of telecommunications services and technologies, namely standardization sector (standard TIER); improving energy efficiency; increasing volumes of traffic and the increasing need to handle arrays of unstructured data; virtualization; modularity/ mobility; productsare; full automation. Analyzed current capacity of the Russian market, Moscow, St. Petersburg and the Leningrad region. The rating of Top-10 companies, hosting equipment in the data centers of St. Petersburg. Ranking of Top 7 most popular services and their cost in St. Petersburg. Installed, the Russian market is lagging behind in its development from the markets of Europe and USA about 5 years. The investigated volume of the cloud market by segment in 2013. Presents forecast of development of the Russian telecommunications market until 2018. The rating of the customer segments of the telecommunication market. Analyzed the share of Russian companies using the installation payment in $\%$ of the rent. Found that the number of data centers on the market will increase, and you may receive the major centers of information processing. The market of commercial data centers develops, will increase the range of services and increase their quality, to decrease the response time to requests, the organization of the original shares for tenants. However, this situation will change as market development, gradually approaching the distribution of already formed on the U.S. market, where the share of commercial operators is only $37 \%$.
\end{abstract}

Keywords: information technology; information processing center (DPC); data centers; market IT; forecast; key trends. 


\section{REFERENCES}

1. Nauchno-tekhnicheskoe razvitie kak innovatsionnyy faktor ekonomicheskogo rosta. [Tekst]: Kollektivnaya monografiya. /Ashalyan L.N., Zhenzhebir V.N., Kolosova G.M., Medvedev V.M., Palastina I.P., Polozhentseva I.V., Pshava T.S., Fadeev A.S., Filatov V.V., Filatov A.V. Izdatel'stvo: TsNTB Pishchevoy promyshlennosti, Moskva: [b. i.], 2014. - $446 \mathrm{~s}$.

2. Regional'nye aspekty upravleniya ipotechnymi kreditnymi rynkami v sub"ektakh RF i munitsipal'nykh obrazovaniyakh. [Tekst]: Kollektivnaya monografiya. / Filatov V.V., Tret'yak A.V., Knyazev V.V., Kobulov B.A., Kolosova G.M., Shestov A.V. Izdatel'stvo: TsNTB Pishchevoy promyshlennosti, Moskva: [b. i.], 2014. - 522 s.

3. Rol' mezhdunarodnykh platezhnykh sistem $\mathrm{v}$ ekonomike Rossii [Tekst]: Kollektivnaya monografiya. / Filatov V.V., Trifonov R. N., Knyazev V.V., Kobulov B.A., Polozhentseva I.V., Shestov A.V. Izdatel'stvo: TsNTB Pishchevoy promyshlennosti, Moskva: [b. i.], 2014. - 462s.

4. Sovershenstvovanie strategicheskogo upravleniya predpriyatiya na osnove situatsionnogo analiza i sbalansirovannoy sistemy pokazateley. [Tekst]: Kollektivnaya monografiya. /Filatov V.V., Dibrova Zh.N., Medvedev V.M., Zhenzhebir V.N., Knyazev V.V., Kobulov B.A., Palastina I.P., Polozhentseva I.V., Kobiashvili N.A., Fadeev A.S., Shestov A.V. Izdatel'stvo: TsNTB Pishchevoy promyshlennosti, Moskva: [b. i.], 2015. - 482 s.

5. Upravlenie litsenzionnoy deyatel'nost'yu: voprosy teorii i praktiki. [Tekst]: Kollektivnaya monografiya. / Ashalyan L.N., Dadugin M.V., Dibrova Zh.N. Zhenzhebir V.N., Kolosova G.M., Medvedev V.M., Pshava T.S., Fadeev A.S., Filatov V.V., Filatov A.V. Izdatel'stvo: TsNTB Pishchevoy promyshlennosti, Moskva: [b. i.], 2013. - 417 s.

6. Upravlenie khozyaystvennymi svyazyami predpriyatiya $\mathrm{s}$ postavshchikami i potrebitelyami [Tekst]: Kollektivnaya monografiya. / Filatov V.V., Mamedov F.A., Medvedev V.M., Knyazev V.V., Kobulov B.A., Fadeev A.S., Shestov A.V., Izdatel'stvo: TsNTB Pishchevoy promyshlennosti, Moskva: [b. i.], 2015.

7. Upravlenie strategiey investitsionno - ekonomicheskogo razvitiya vertikal'nointegrirovannogo kholdinga [Tekst]: Kollektivnaya monografiya. /Filatov V.V., Trifonov R.N., Podlesnaya L.V., Borisova T.A., Medvedev V.M., Knyazev V.V., Fadeev A.S., Shestov A.V. Izdatel'stvo: TsNTB Pishchevoy promyshlennosti, Moskva: [b. i.], 2015.

8. Upravlenie stoimost'yu tovarnogo znaka kak ob"ekta otsenki $\mathrm{v}$ tselyakh ego kommertsializatsii [Tekst]: Kollektivnaya monografiya. / Filatov V.V., Knyazev V.V., Kobulov B.A., Shestov A.V. Izdatel'stvo: TsNTB Pishchevoy promyshlennosti, Moskva: [b. i.], 2015.

9. Filatov V.V., Palastina I.P., Dadugin M.V., Nurmagomedova N.V., Safronov B.I. Analiz sistem upravleniya stoimost'yu biznesa na osnove sovremennykh informatsionnykh tekhnologiy. Nauchno-teoreticheskiy zhurnal «Voprosy gumanitarnykh nauk» - Vypusk №2(52), Izdatel'stvo «Sputnik+», 2011 - S.21-26.

10. Medvedeva T.Yu., Khomutinnikova T.V., Filatov V.V. Upravlenie tekhnologicheskimi innovatsiyami $\mathrm{v}$ APK na osnove sozdaniya $\mathrm{i}$ razvitiya 
informatsionno - konsul'tatsionnykh sistem. // Mat.-ly Mezhdunarodnoy nauchnoprakticheskoy konferentsii «Innovatsionnaya politika khozyaystvuyushchego sub"ekta: tseli, problemy, puti sovershenstvovaniya»., sektsiya: «Kontseptual'nye osobennosti sovremennogo menedzhmenta», M.:MVTs «Krokus - Ekspo», RUDN, 2011, S.496-503.

11. Deeva V.A., Filatov V.V., Aktual'nye voprosy perekhoda regional'noy ekonomiki RF na innovatsionnyy put' razvitiya $\mathrm{v}$ usloviyakh sovremennoy informatsionnoy sredy. //Mat.-ly VIII Mezhdunarodnoy nauchnoy konferentsii «Obrazovanie, ekonomika, pravo v sovremennom informatsionnom obshchestve», Chast' III. M.: Moskovskiy Universitet im. S.Yu. Vitte, 2012 - S.136-142.

12. Filatov V.V., Eliseeva T.V. Analiz natsional'noy innovatsionnoy sistemy RF na osnove strategicheskoy kontseptsii sotsial'no-ekonomicheskogo razvitiya regionov $\mathrm{v}$ usloviyakh sovremennoy informatsionnoy sredy. //Mat.-ly VIII Mezhdunarodnoy nauchnoy konferentsii «Obrazovanie, ekonomika, pravo $\mathrm{v}$ sovremennom informatsionnom obshchestve», Chast' III. M.: Moskovskiy Universitet im. S.Yu. Vitte, 2012- S.231-238.

13. Filatov V.V. Novaya paradigma prostranstvennoy organizatsii innovatsionnoy ekonomiki RF $\mathrm{v}$ usloviyakh narastayushchey globalizatsii i sovremennoy informatsionnoy sredy. Mat.-ly II Mezhdunarodnoy nauchno-prakticheskoy konferentsii «Evraziyskoe prostranstvo: prioritety sotsial'no-ekonomicheskogo razvitiya», M.:EOI, 2012 - S.623-632.

14. Filatov V.V., Kobulova A.B. Informatsionnye tekhnologii upravleniya proektnym innovatsionnym tsiklom. VIII-ya Mezhdunarodnaya nauchno-prakticheskaya konferentsiya, posvyashchennaya 125-letiyu osnovaniya g. Unecha «Teoriya i praktika strategicheskogo planirovaniya razvitiya infra-struktury munitsipal'nykh obrazovaniy», Sbornik nauchnykh trudov, Tom 2 - S.116-133, 2012.

15. Filatov V.V., Karasev M.V. Vliyanie informatsionno-kommunikatsionnykh tekhnologiy na sovremennye metody upravleniya, osnovannye na ekonomicheskoy optimizatsii innovatsiy. // Materialy mezhdunarodnoy nauchno-prakticheskoy konferentsii «Dostizheniya nauki za poslednie gody. Novye narabotkilPostepy w nauce w ostatnich latach. Nowych rozwiazan.» VarshavalWarszawa, Pol'sha\ Poland: Izdatel'skaya gruppa \Publishing group «Diamond trading tour», 2012, S.48-60.

16. Karasev M.V., Filatov V.V., Sovershenstvovanie strategicheskogo upravleniya innovatsionnymi proektami predpriyatiya na osnove sovremennykh ekonomikomatematicheskikh metodov v usloviyakh informatsionnoy sredy i narastayushchey globalizatsii //Nauchno - prakticheskiy zhurnal «Kachestvo. Innovatsii. Obrazovanie» №1, 2013, S.35-50.

17. Filatov V.V., Dadugin M.V. Regional'nye aspekty upravleniya informatsionnoekonomicheskim razvitiem sovremennykh innovatsionnykh predpriyatiy na osnove vnedreniya sistemy kontrollinga. // Teoreticheskiy i nauchno - metodicheskiy zhurnal «Vestnik Universiteta», № 14, 2012, S.141-149.

18. Informatsionnoe obespechenie i forsaytnye issledovaniya innovatsionnoy deyatel'nosti predpriyatiy. Kolosova G.M., Denisova N.A., Ashalyan L.N., Filatov V.V. // Teoreticheskiy i nauchno - metodicheskiy zhurnal «Vestnik Universiteta», № 13, 2012, S.17-25. 